$11,09,04$

\title{
Предпереходные явления в области фазовых переходов первого рода в ионно-молекулярных кристаллах
}

\author{
(C) А.Р. Алиев, И.Р. Ахмедов, М.Г. Какагасанов, З.А. Алиев \\ Институт фозики им. Х.И. Амирханова ДФИЦ РАН, \\ Махачкала, Россия \\ E-mail: amilaliev@rambler.ru
}

Поступила в Редакцию 30 декабря 2019 г.

В окончательной редакции 30 декабря 2019 г.

Принята к публикации 10 января 2020 г.

\begin{abstract}
Методами спектроскопии комбинационного рассеяния (КР) исследованы процессы молекулярной релаксации в сульфатах $\mathrm{Li}_{2} \mathrm{SO}_{4}, \mathrm{Na}_{2} \mathrm{SO}_{4}, \mathrm{~K}_{2} \mathrm{SO}_{4}$, карбонатах $\mathrm{Li}_{2} \mathrm{CO}_{3}, \mathrm{Na}_{2} \mathrm{CO}_{3}, \mathrm{~K}_{2} \mathrm{CO}_{3}$, перхлоратах $\mathrm{NaClO}_{4}, \mathrm{KClO}_{4}$ и нитратах $\mathrm{Ca}\left(\mathrm{NO}_{3}\right)_{2}, \mathrm{Sr}\left(\mathrm{NO}_{3}\right)_{2}, \mathrm{Ba}\left(\mathrm{NO}_{3}\right)_{2}$. Установлено, что в исследованных системах фазовые переходы первого рода носят растянутый характер: в сульфатах, карбонатах и перхлоратах - это структурные фазовые переходы, а в нитратах - это фазовый переход „кристалл-расплав“Ӧбнаружено существование предпереходной области во всех исследованных кристаллах.
\end{abstract}

Ключевые слова: ионные кристаллы, комбинационное рассеяние, молекулярная спектроскопия, колебательная релаксация, предпереход, расплав, предплавление.

DOI: 10.21883/FTT.2020.06.49344.34M

\section{1. Введение}

Исследованиям фазовых переходов в кристаллах в последние годы уделяется большое внимание [1-16]. Многие из них являются переходами первого рода. Известно, что в области фазового перехода первого рода „кристалл-расплав“ имеют место явления предплавления $[17,18]$. Предпереходные явления наблюдаются в жидких кристаллах [19-22]. Исследованы предпереходные явления в металлических сплавах [23-26].

Можно предположить, что подобные предпереходные явления могут наблюдаться и при некоторых структурных фазовых переходах первого рода в кристаллах. Наряду с дифракционными методами эти явления могут с успехом изучаться и спектроскопическими методами, чувствительными к локальным взаимодействиям и нарушениям в кристаллической решетке.

В работах [27-30] исследовались структурные фазовые переходы первого рода в кристаллах $\mathrm{KPb}_{2} \mathrm{Br}_{5}$, $\left(\mathrm{NH}_{4}\right)_{2} \mathrm{WO}_{2} \mathrm{~F}_{4}, \mathrm{KPb}_{2} \mathrm{Cl}_{5},\left(\mathrm{NH}_{4}\right)_{2} \mathrm{NbOF}_{5}$. При повышении температуры разность показателей преломления сначала изменялась линейно и незначительно, а за $30-130 \mathrm{~K}$ до температуры фазового перехода наблюдается аномальное поведение двупреломления. Эта особая температурная точка на температурных зависимостях. В этих кристаллах в широком интервале температур выше фазового перехода наблюдались сильные предпереходные явления, растянутые по температуре на 30-70 K.

Теоретические представления о предпереходных состояниях развиты в работах [31-34]. В последние годы представления о предпереходных явлениях развиты в работах [35-40].

В качестве метода исследования структурных фазовых переходов в кристаллах удобен метод колебательной спектроскопии, в том числе и метод комбинационного рассеяния (КР) света $[41,42]$. В отличие от других методов в колебательной спектроскопии измеряются величины, характеризующие непосредственно отдельные молекулы или ионы изучаемой системы. Этими параметрами являются положение максимума (частота $v$ ) и ширина $w$ спектральной полосы. Малейшие изменения в микроскопической структуре и строении изучаемой системы, а также в динамике молекул и ионов отражаются на спектральных параметрах $(v, w)$ этой системы.

Поэтому исследование предпереходных явлений при фазовых переходах первого рода в кристаллах методом КР может способствовать установлению характера изменения механизма ионной динамики при структурном фазовом превращении и плавлении. Тем более что при исследовании фазовых переходов типа „порядокбеспорядок“ в нитратах щелочных металлов обнаружены предпереходные явления, изучение которых важно для понимания динамики процессов разупорядочения и ориентационного плавления в области растянутых фазовых переходов $[43,44]$. С точки зрения структуры рассматриваемых фаз, некоторые превращения в твердом состоянии оказываются чрезвычайно важными для исследования и интерпретации процессов плавления.

В наших предыдущих работах мы исследовали область предплавления в кристаллах с многоатомными ионами методом колебательной спектроскопии [45]. При этом было установлено, что область предплавления наиболее четко проявляется в тех кристаллах, где выше симметрия молекулярного иона. В соответствии с этим, в настоящей работе в качестве объектов исследования нами были выбраны сульфаты и карбонаты лития, натрия и калия $\left(\mathrm{Li}_{2} \mathrm{SO}_{4}, \mathrm{Na}_{2} \mathrm{SO}_{4}, \mathrm{~K}_{2} \mathrm{SO}_{4}, \mathrm{Li}_{2} \mathrm{CO}_{3}\right.$, $\left.\mathrm{Na}_{2} \mathrm{CO}_{3}, \mathrm{~K}_{2} \mathrm{CO}_{3}\right)$, перхлораты натрия и калия $\left(\mathrm{NaClO}_{4}\right.$, 
$\left.\mathrm{KClO}_{4}\right)$ и нитраты кальция, стронция и бария $\left(\mathrm{Ca}\left(\mathrm{NO}_{3}\right)_{2}\right.$, $\left.\mathrm{Sr}\left(\mathrm{NO}_{3}\right)_{2}, \mathrm{Ba}\left(\mathrm{NO}_{3}\right)_{2}\right)$. Указанные соли содержат симметричные молекулярные анионы $\mathrm{SO}_{4}^{2-}, \mathrm{CO}_{3}^{2-}, \mathrm{ClO}_{4}^{-}, \mathrm{NO}_{3}^{-}$, имеющие определенные наборы нормальных колебаний с хорошо изученным спектром и активных в КР во всех фазовых состояниях. Это позволяет нам надеяться на то, что исследование колебательных спектров вблизи структурного превращения или плавления позволит обнаружить предпереходную область. Исследование фазового перехода в данных кристаллах важно для понимания механизма и молекулярной природы структурных перестроек в твердых телах. В литературе мало данных посвященных исследованиям именно этих классов ионных соединений. Поэтому исследование реориентационной подвижности и процессов разупорядочения анионов в области полиморфных превращений в сульфатах, карбонатах и перхлоратах щелочных металлов и вблизи плавления в нитратах щелочноземельных металлов методом КР является актуальной задачей.

Таким образом, в настоящей работе мы исследуем спектры КР сульфатов и карбонатов лития, натрия и калия, перхлоратов натрия и калия в окрестности структурного фазового перехода и нитратов кальция, стронция и бария вблизи плавления с целью выявить предпереходную область при фазовых переходах первого рода.

\section{2. Объекты исследования}

Сульфат лития $\mathrm{Li}_{2} \mathrm{SO}_{4}$ представляет собой бесцветный кристалл с моноклинной решеткой пространственной группы $C_{2 h}^{5}\left(P 2_{1} / c\right)$. Переход в кубическую форму пространственной группы $T_{d}^{3}(I \overline{4} 3 m)$ происходит при температуре $T_{s}=848-859 \mathrm{~K}$, температура плавления равна $T_{m}=1131-1133 \mathrm{~K}$ [46-48]. По нашим данным $T_{s}=847 \mathrm{~K}$ (рис. 1 ), $T_{m}=1130 \mathrm{~K}[13]$.

Сульфат натрия $\mathrm{Na}_{2} \mathrm{SO}_{4}$ представляет собой бесцветный кристалл, известный в четырех полиморфных модификациях. При температурах ниже $185^{\circ} \mathrm{C}$ имеет место ромбическая $\alpha$-модификация пространственной группы $D_{2 h}^{24}(F d d d)$. В интервале температур $458-514 \mathrm{~K}$ существует ромбическая $\beta$-модификация. При температурах $514-870 \mathrm{~K}$ устойчива гексагональная $\gamma$-модификация пространственной группы $C_{6 v}^{4}\left(P 6_{3} m c\right)$. При температурах выше $870 \mathrm{~K}$ имеет место ромбическая модификация [46]. По данным [47,48] структурный фазовый переход происходит при $T_{s}=520-522 \mathrm{~K}$, по нашим данным $T_{s}=524 \mathrm{~K}$ (рис. 1). Температура плавления $T_{m}=$ $=1157 \mathrm{~K}$ [46-49], по нашим данным $T_{m}=1157 \mathrm{~K}$ [13].

Сульфат калия $\mathrm{K}_{2} \mathrm{SO}_{4}$ есть бесцветный кристалл ромбической сингонии пространственной группы $D_{2 h}^{16}$ (Pnam.) Переход в гексагональную модификацию пространственной группы $D_{6 h}^{4}\left(P 6_{3} / m m c\right)$ происходит при $T_{s}=856-857 \mathrm{~K} \quad[46-48]$, по нашим данным $T_{s}=854 \mathrm{~K}$ (рис. 1). Температура плавления равна $T_{m}=$ $=1342-1347 \mathrm{~K} \quad[46-49], \quad$ по нашим данным $T_{m}=1343 \mathrm{~K}[13]$.

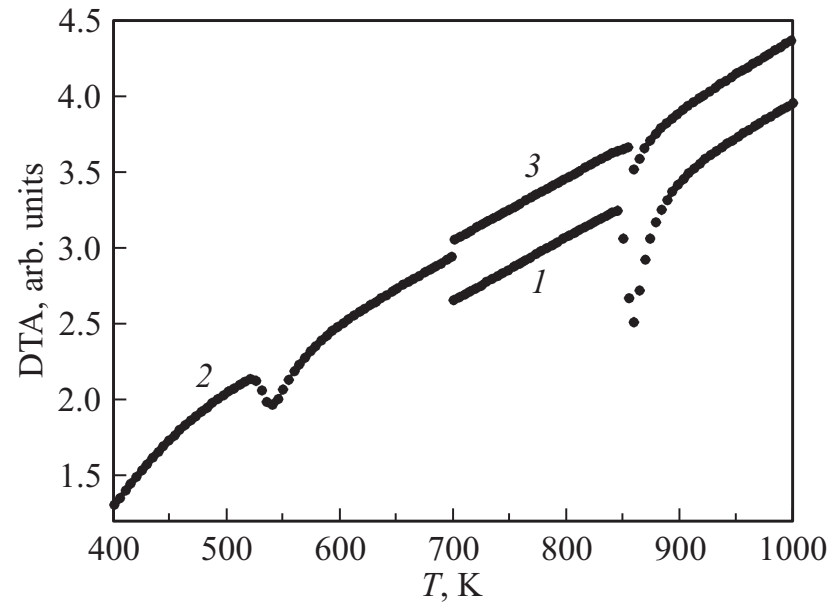

Рис. 1. Кривые дифференциального термического анализа (DTA) для сульфатов лития $\mathrm{Li}_{2} \mathrm{SO}_{4}(1)$, натрия $\mathrm{Na}_{2} \mathrm{SO}_{4}(2)$ и калия $\mathrm{K}_{2} \mathrm{SO}_{4}(3)$.

Карбонат лития $\mathrm{Li}_{2} \mathrm{CO}_{3}$ представляет собой бесцветный кристалл с моноклинной решеткой пространственной группы $C_{2 h}^{6}(C 2 / c)$, температура плавления равна $T_{m}=993-1005 \mathrm{~K}$ [46-48]. По некоторым данным [47] при $T_{s}=683 \mathrm{~K}$ в $\mathrm{Li}_{2} \mathrm{CO}_{3}$ происходит структурный фазовый переход.

Карбонат натрия $\mathrm{Na}_{2} \mathrm{CO}_{3}$ представляет собой бесцветный кристалл. При температурах ниже $623 \mathrm{~K}[46,48]$ существует $\alpha$-модификация с моноклинной решеткой пространственной группы $C_{2}^{3}(C 2)$ или $C_{5}^{3}(C m)$. В интервале температур $632-752 \mathrm{~K}$ существует $\beta$-модификация с моноклинной кристаллической решеткой, а выше $758 \mathrm{~K}-$ гексагональная $\gamma$-модификация пространственной группы $C_{6 v}^{4}\left(P 6_{3} m c\right)[46,48,49]$. Температура плавления равна $T_{m}=1123-1131 \mathrm{~K}[46-49]$.

Карбонат калия $\mathrm{K}_{2} \mathrm{CO}_{3}$ - это бесцветный кристалл моноклинной сингонии пространственной группы $C_{2 h}^{5}\left(P 2_{1} / c\right)$. Переход в гексагональную модификацию происходит при температуре $T_{s}=693-695 \mathrm{~K}[46,48]$. Температура плавления $T_{m}=1164-1178 \mathrm{~K}$ [46-49].

Перхлорат лития $\mathrm{LiClO}_{4}$ представляет собой бесцветный кристалл гексагонального типа группы $C_{6 v}^{4}\left(P 6_{3} m c\right)$, температура плавления которого равна $T_{m}=520 \mathrm{~K}$ (по другим данным $T_{m}=509 \mathrm{~K}$ ), температура разложения составляет $673 \mathrm{~K}$ [46]. По нашим данным $T_{m}\left(\mathrm{LiClO}_{4}\right)=517 \mathrm{~K}$ (рис. 2).

Перхлорат натрия $\mathrm{NaClO}_{4}$ по известным данным имеет две кристаллические модификации: низкотемпературную орторомбическую $D_{2 h}^{17}(\mathrm{Cmcm})$ и высокотемпературную ГЦК $O_{h}^{5}(F m \overline{3} m)$, температура перехода равна $T_{\text {str }}\left(\mathrm{NaClO}_{4}\right)=579-581 \mathrm{~K}$, температура плавления $T_{m}=742 \mathrm{~K}$ [46]. По нашим данным $T_{s}\left(\mathrm{NaClO}_{4}\right)=581 \mathrm{~K}$, $T_{m}\left(\mathrm{NaClO}_{4}\right)=745 \mathrm{~K}$ (рис. 2).

Низкотемпературная фаза перхлората калия $\mathrm{KClO}_{4}$ имеет орторомбическую структуру типа барита, пространственная группа $D_{2 h}^{16}($ Pnта $)$. При $T_{s}\left(\mathrm{KClO}_{4}\right)=$ $=573 \mathrm{~K}$ происходит переход в кубическую структуpy с пространственной группой $T^{4}\left(P 2{ }_{1} 3\right)$, температура 


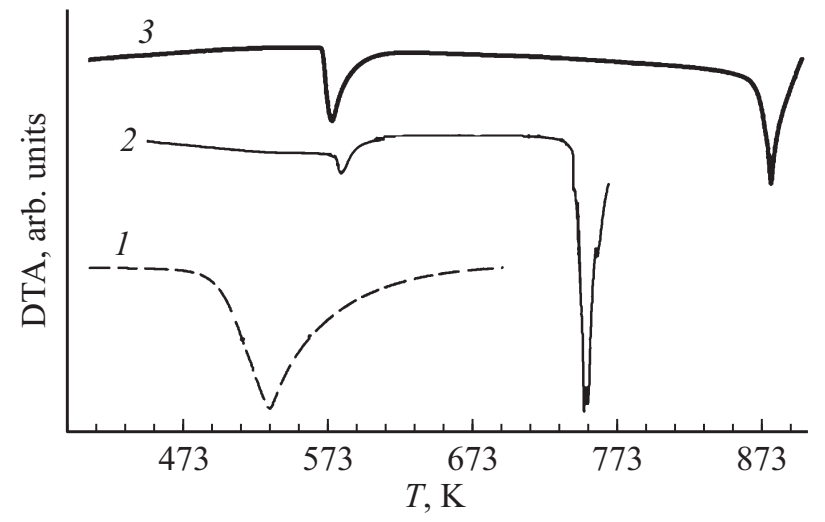

Рис. 2. Кривые дифференциального термического анализа (DTA) для перхлоратов лития $\mathrm{LiClO}_{4}(1)$, натрия $\mathrm{NaClO}_{4}$ (2) и калия $\mathrm{KClO}_{4}(3)$.

плавления $T_{m}\left(\mathrm{KClO}_{4}\right)=853 \mathrm{~K}$ [46]. По нашим данным $T_{\text {str }}\left(\mathrm{KClO}_{4}\right)=571 \mathrm{~K}, T_{m}\left(\mathrm{KClO}_{4}\right)=863 \mathrm{~K}$ (рис. 2 ).

Нитрат кальция $\mathrm{Ca}\left(\mathrm{NO}_{3}\right)_{2}$ представляет собой бесцветный кристалл с кубической решеткой $(a=0.762 \mathrm{~nm}$, $z=4$, пространственная группа $\left.-T_{h}^{6}-P a \overline{3}\right)$; температура плавления $T_{m}=834 \mathrm{~K}[46]$.

Нитрат стронция $\mathrm{Sr}\left(\mathrm{NO}_{3}\right)_{2}$ представляет собой бесцветный кристалл с кубической решеткой $(a=0.781 \mathrm{~nm}$, $z=4$, пространственная группа $\left.-T_{h}^{6}-P a \overline{3}\right)$; температура плавления $T_{m}=918 \mathrm{~K}[46]$.

Нитрат бария $\mathrm{Ba}\left(\mathrm{NO}_{3}\right)_{2}$ представляет собой бесцветный кристалл с кубической решеткой $(a=0.813 \mathrm{~nm}$, пространственная группа $\left.T^{4}-P 2{ }_{1} 3\right)$; температура плавления $T_{m}=868 \mathrm{~K}[46]$.

\section{3. Эксперимент}

Дифференциальный термический анализ DTA проводился на приборе синхронного термического анализа STA 449 F3 Jupiter („NETZSCH“) при скорости нагрева $20 \mathrm{~K} / \mathrm{min}$ в атмосфере аргона в алундовых тиглях (рис. 1,2) в АЦКП ДНЦ РАН. Обработка данных и интегрирование пиков проводились с помощью встроенных прикладных программ фирмы „NETZSCH“.

Для получения информации о динамических межионных взаимодействиях нами использован анализ формы контуров колебаний молекулярных анионов в спектрах КР твердой системы. Непосредственно из фононного спектра получить подобную информацию не представляется возможным. Спектр малых частот высокотемпературных фаз ионных кристаллов, как правило, регистрируется в виде широкой бесструктурной полосы, обусловленной термическим смешением различных типов (трансляционных, либрационных) внешних колебаний структурных единиц.

В то же время, изменения структуры и динамики твердой системы оказывает влияние на колебательные состояния ее структурных единиц и отражается в спектрах инфракрасного поглощения и КР. Поэтому использование колебательных спектров, соответствующих внутренним модам молекулярных ионов, для получения информации о процессах молекулярной релаксации в ионных кристаллах и расплавах представляется вполне обоснованным.

Спектры КР возбуждались излучением аргонового лазера ЛГ-106м-1 с длиной волны $\lambda=488 \mathrm{~nm}$ и регистрировались спектрометром ДФС-52М от 850 до $1170 \mathrm{~cm}^{-1}$ в области валентных полносимметричных колебаний $v_{1}(\mathrm{~A})$ сульфат-иона $v_{1}\left(\mathrm{SO}_{4}^{2-}\right) \approx 960-1006 \mathrm{~cm}^{-1}$, карбонат-иона $v_{1}\left(\mathrm{CO}_{3}^{2-}\right) \approx 1040-1080 \mathrm{~cm}^{-1}, \quad$ перхлоратиона $v_{1}\left(\mathrm{ClO}_{4}^{-}\right) \approx 920-950 \mathrm{~cm}^{-1}$, нитрат-иона $v_{1}\left(\mathrm{NO}_{3}^{-}\right) \approx$ $\approx 1030-1060 \mathrm{~cm}^{-1}$ в температурном интервале 293-950 К. Ширины входной и выходной щелей монохроматора устанавливались одинаковыми и в зависимости от интенсивности рассеяния выбирались от $100 \mu \mathrm{m}$ до $200 \mu \mathrm{m}$. Положения максимумов колебательных полос фиксировалось с точностью $\pm 0.5 \mathrm{~cm}^{-1}$, а их ширины с точностью $\pm 0.1 \mathrm{~cm}^{-1}$. Температура образцов поддерживалась в процессе регистрации спектров с точностью $\pm 0.5 \mathrm{~K}$. Методика регистрации и обработки спектров КР подробно описана в [50-55].

На рис. 3 показаны спектры КР сульфатов $\mathrm{Li}_{2} \mathrm{SO}_{4}$, $\mathrm{Na}_{2} \mathrm{SO}_{4}, \mathrm{~K}_{2} \mathrm{SO}_{4}$ в области колебания $v_{1}(\mathrm{~A})$ сульфатиона $\mathrm{SO}_{4}^{2-}$. На рис. 4 показаны спектры КР карбонатов $\mathrm{Li}_{2} \mathrm{CO}_{3}, \mathrm{Na}_{2} \mathrm{CO}_{3}, \mathrm{~K}_{2} \mathrm{CO}_{3}$ в области колебания $v_{1}(\mathrm{~A})$ карбонат-иона $\mathrm{CO}_{3}^{2-}$. На рис. 5 показаны спектры КР перхлоратов $\mathrm{NaClO}_{4}$ и $\mathrm{KClO}_{4}$ в области колебания $v_{1}(\mathrm{~A})$ перхлорат-иона $\mathrm{ClO}_{4}^{-}$. Рис. 6. показаны спектры КР нитратов $\mathrm{Ca}\left(\mathrm{NO}_{3}\right)_{2}, \mathrm{Sr}\left(\mathrm{NO}_{3}\right)_{2}, \mathrm{Ba}\left(\mathrm{NO}_{3}\right)_{2}$ в области колебания $v_{1}(\mathrm{~A})$ нитрат-иона $\mathrm{NO}_{3}^{-}$. Контуры рассматриваемых колебаний резко поляризованы (изотропное рассеяние) и потому их формирование всецело можно приписать процессам колебательной релаксации.

На рис. 7-12 представлены температурные зависимости частот $v$ (рис. 7,9,11), ширин $w$ и интенсивностей $I$ (рис. $8,10,12)$ контура $v_{1}(\mathrm{~A})$ колебания $\mathrm{SO}_{4}^{2-}$ в суль-

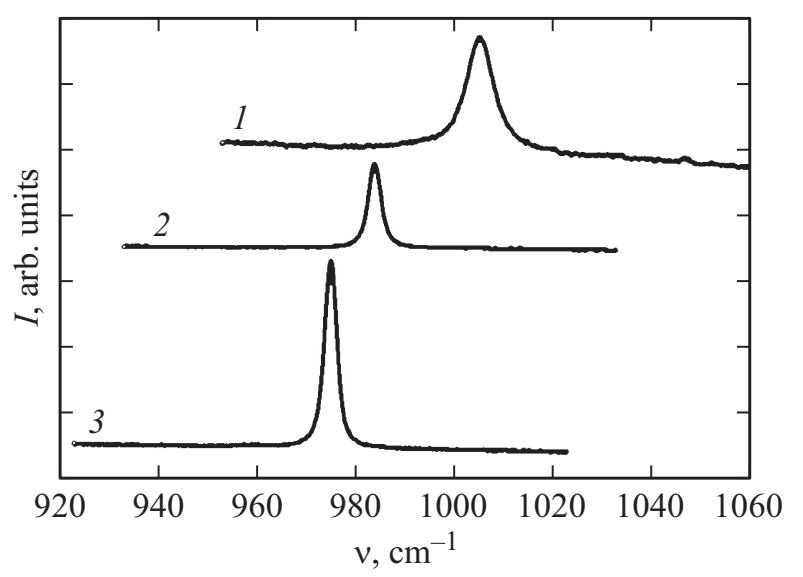

Рис. 3. Спектры КР сульфатов лития $\mathrm{Li}_{2} \mathrm{SO}_{4}$ (1), натрия $\mathrm{Na}_{2} \mathrm{SO}_{4}$ (2) и калия $\mathrm{K}_{2} \mathrm{SO}_{4}$ (3) в области валентного полносимметричного колебания $v_{1}(\mathrm{~A})$ сульфат-иона $\mathrm{SO}_{4}^{2-}$ при температурах $T=298 \mathrm{~K}(1), 293 \mathrm{~K}(2,3)$ и ширинах входной и выходной щелей монохроматора $150 \mu \mathrm{m}(1), 100 \mu \mathrm{m}(2,3)$. 


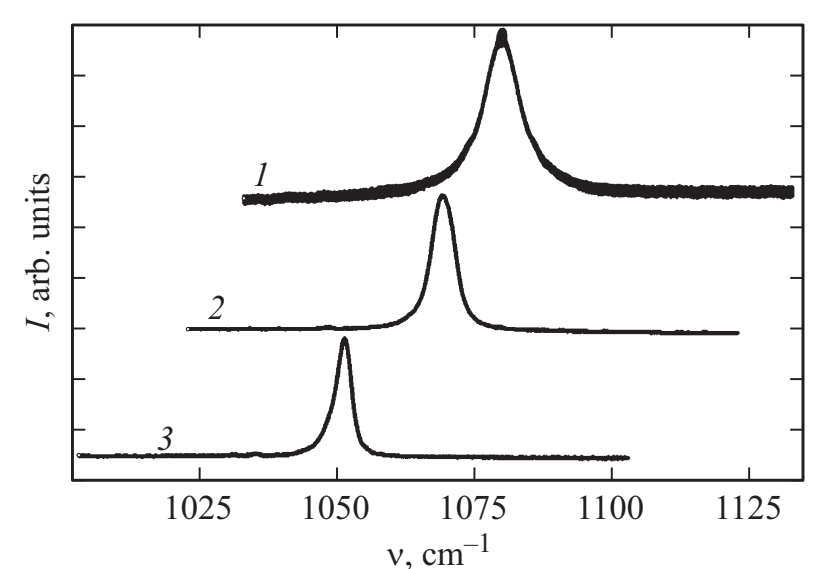

Рис. 4. Спектры КР карбонатов лития $\mathrm{Li}_{2} \mathrm{CO}_{3}$ (1), натрия $\mathrm{Na}_{2} \mathrm{CO}_{3}$ (2) и калия $\mathrm{K}_{2} \mathrm{CO}_{3}(3)$ в области валентного полносимметричного колебания $v_{1}(\mathrm{~A})$ карбонат-иона $\mathrm{CO}_{3}^{2-}$ при температуре $T=473 \mathrm{~K}$ и ширинах входной и выходной щелей монохроматора $150 \mu \mathrm{m}(1), 100 \mu \mathrm{m}(2,3)$.

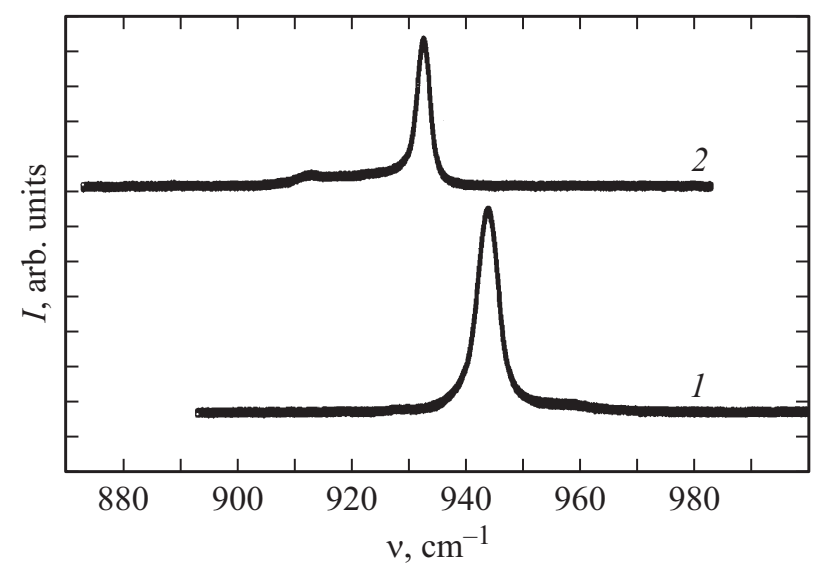

Рис. 5. Спектры КР перхлоратов натрия $\mathrm{NaClO}_{4}$ при $T=308 \mathrm{~K}(1)$ и калия $\mathrm{KClO}_{4}$ при $T=313 \mathrm{~K}$ (2) в области валентного полносимметричного колебания $v_{1}(\mathrm{~A})$ перхлоратиона $\mathrm{ClO}_{4}^{-}$при ширинах входной и выходной щелей монохроматора $150 \mu \mathrm{m}$.

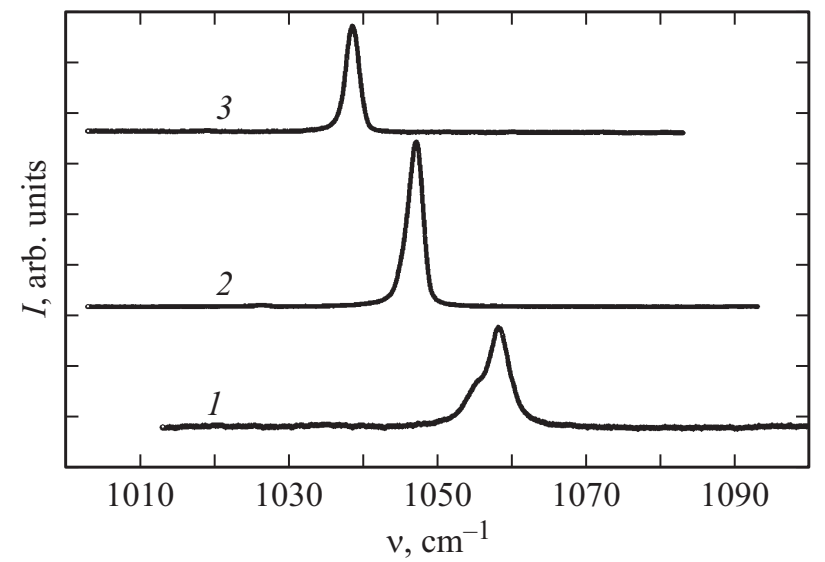

Рис. 6. Спектры КР нитратов кальция $\mathrm{Ca}\left(\mathrm{NO}_{3}\right)_{2}(1)$, стронция $\mathrm{Sr}\left(\mathrm{NO}_{3}\right)_{2}$ (2), бария $\mathrm{Ba}\left(\mathrm{NO}_{3}\right)_{2}$ (3) в о бласти валентного полносимметричного колебания $v_{1}(\mathrm{~A})$ нитрат-иона $\mathrm{NO}_{3}^{-}$при температуре $T=298 \mathrm{~K}$ и ширинах входной и выходной щелей монохроматора $100 \mu \mathrm{m}$. фатах $\mathrm{Li}_{2} \mathrm{SO}_{4}$ (рис. 7,8), $\mathrm{Na}_{2} \mathrm{SO}_{4}$ (рис. 9,10) и $\mathrm{K}_{2} \mathrm{SO}_{4}$ (рис. 11, 12).

На рис. 13-18 представлены температурные зависимости частот $v$ (рис. $13,15,17$ ), ширин $w$ и интенсивностей $I$ (рис. $14,16,18)$ контура $v_{1}(\mathrm{~A})$ колебания $\mathrm{CO}_{3}^{2-}$ в карбонатах $\mathrm{Li}_{2} \mathrm{CO}_{3}$ (рис. 13,14), $\mathrm{Na}_{2} \mathrm{CO}_{3}$ (рис. 15,16 ) и $\mathrm{K}_{2} \mathrm{CO}_{3}$ (рис. 17, 18).

На рис. 19-22 представлены температурные зависимости частот $v$ (рис. 19,21), ширин $\mathrm{w}$ и интенсивностей $I$ (рис. 20,22) контура $v_{1}(\mathrm{~A})$ колебания $\mathrm{ClO}_{4}^{-}$в перхлоратах $\mathrm{NaClO}_{4}$ (рис. 19,20) и $\mathrm{KClO}_{4}$ (рис. 21, 22).

На рис. 23-28 представлены температурные зависимости частоты $v$ (рис. 23, 25, 27), ширины $w$ и интенсивности $I$ (рис. $24,26,28)$ контура $v_{1}(\mathrm{~A})$ колебания $\mathrm{NO}_{3}^{-}$в нитратах $\mathrm{Ca}\left(\mathrm{NO}_{3}\right)_{2}$ (рис. 23, 24), $\mathrm{Sr}\left(\mathrm{NO}_{3}\right)_{2}$ (рис. 25, 26), $\mathrm{Ba}\left(\mathrm{NO}_{3}\right)_{2}$ (рис. 27, 28).

Повышение температуры кристаллов от комнатной до температуры фазового перехода приводит к изменению параметров практически всех, наблюдаемых в спектре полос. Общим свойством для всех спектров является смещение максимумов в низкочастотную область, уширение спектральных линий и упрощение их формы по мере повышения температуры и при переходе из низкотемпературной в высокотемпературную фазу. Вместе с тем для каждого кристалла наблюдаются свои особенности изменения спектров при температурных изменениях и фазовых превращениях. Поэтому ниже приведем обсуждение применительно к каждой соли в отдельности.

\section{4. Обсуждение}

На рис. 7 представлена температурная зависимость $v(T)$ положения максимума спектральной полосы, соответствующей колебанию $v_{1}(\mathrm{~A})$ аниона $\mathrm{SO}_{4}^{2-}$ в сульфате лития $\mathrm{Li}_{2} \mathrm{SO}_{4}$. С ростом температуры частота колебания уменьшается. Примерно при $T_{p}=650-700 \mathrm{~K}$ имеют место определенные особенности температурной зависимости $v(T)$. При дальнейшем увеличении температуры уменьшение частоты происходит более быстро. В точке структурного фазового перехода первого рода $\left(T_{s} \approx 850 \mathrm{~K}\right)$ частота резко уменьшается. Таким образом, в интервале температур от 650 до $850 \mathrm{~K}$ имеет место предпереходная область в сульфате лития $\mathrm{Li}_{2} \mathrm{SO}_{4}$.

На рис. 8 представлены температурные зависимости $w(T)$ ширины $(I)$ и $I(T)$ интенсивности (2) спектральной полосы, соответствующей колебанию $v_{1}(\mathrm{~A})$ аниона $\mathrm{SO}_{4}^{2-}$ в сульфате лития $\mathrm{Li}_{2} \mathrm{SO}_{4}$. С ростом температуры ширина возрастает, а интенсивность уменьшается. Примерно при $T_{p}=650-700 \mathrm{~K}$ имеют место определенные особенности температурных зависимостей $w(T)$ и $I(T)$. Интенсивность резко возрастает при $T_{p}=650 \mathrm{~K}$, а затем постепенно уменьшается. Ширина при $T_{p}=650 \mathrm{~K}$ начинает увеличиваться медленнее и резко возрастает в точке структурного фазового перехода первого рода $\left(T_{s} \approx 850 \mathrm{~K}\right)$. Таким образом, в интервале температур от 650 до $850 \mathrm{~K}$ имеет место предпереходная область в сульфате лития $\mathrm{Li}_{2} \mathrm{SO}_{4}$. 


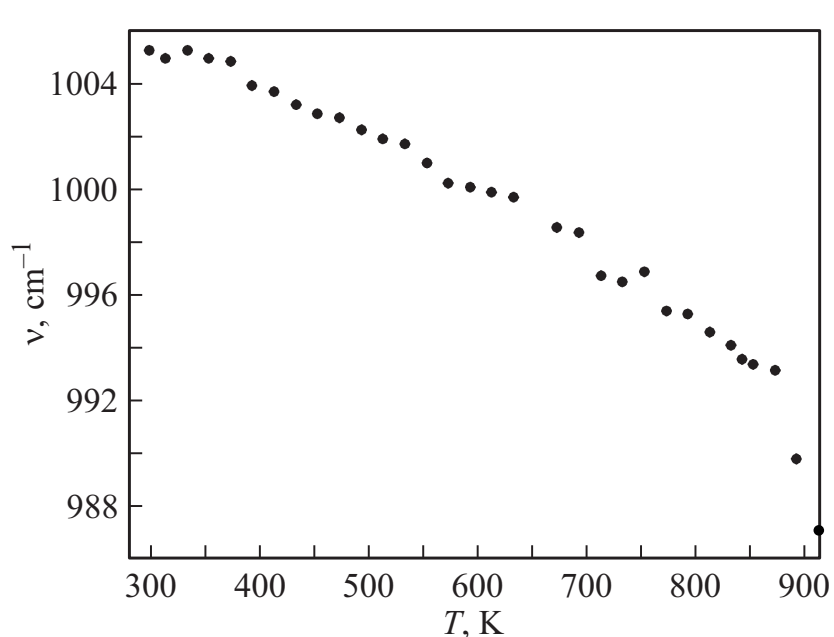

Рис. 7. Температурная зависимость $v(T)$ положения максимума спектрального контура $\nu_{1}(\mathrm{~A})$ аниона $\mathrm{SO}_{4}^{2-}$ в кристаллическом сульфате лития $\mathrm{Li}_{2} \mathrm{SO}_{4}$.

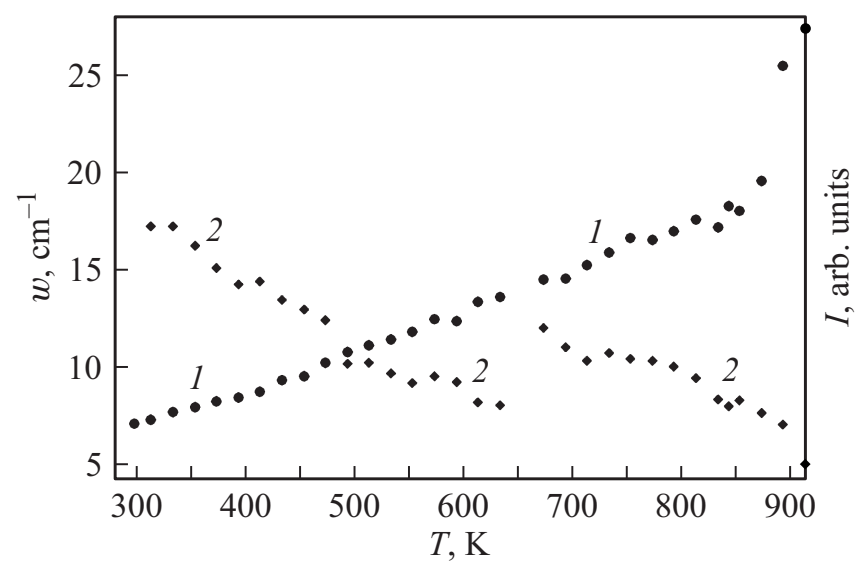

Рис. 8. Температурные зависимости ширины $w(T)(1)$ и интенсивности $I(T)(2)$ спектрального контура $v_{1}(\mathrm{~A})$ аниона $\mathrm{SO}_{4}^{2-}$ в кристаллическом сульфате лития $\mathrm{Li}_{2} \mathrm{SO}_{4}$.

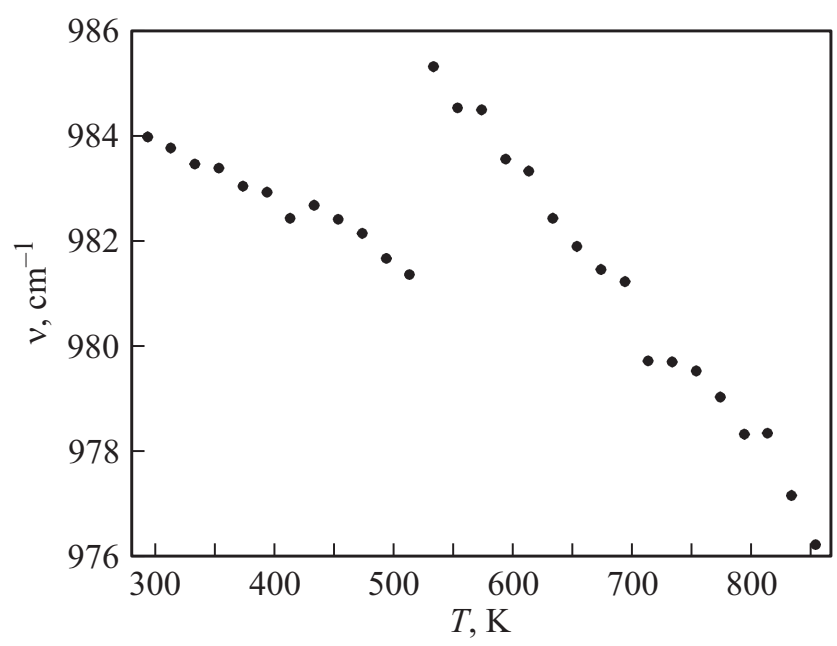

Рис. 9. Температурная зависимость $v(T)$ положения максимума спектрального контура $v_{1}(\mathrm{~A})$ аниона $\mathrm{SO}_{4}^{2-}$ в кристаллическом сульфате натрия $\mathrm{Na}_{2} \mathrm{SO}_{4}$.

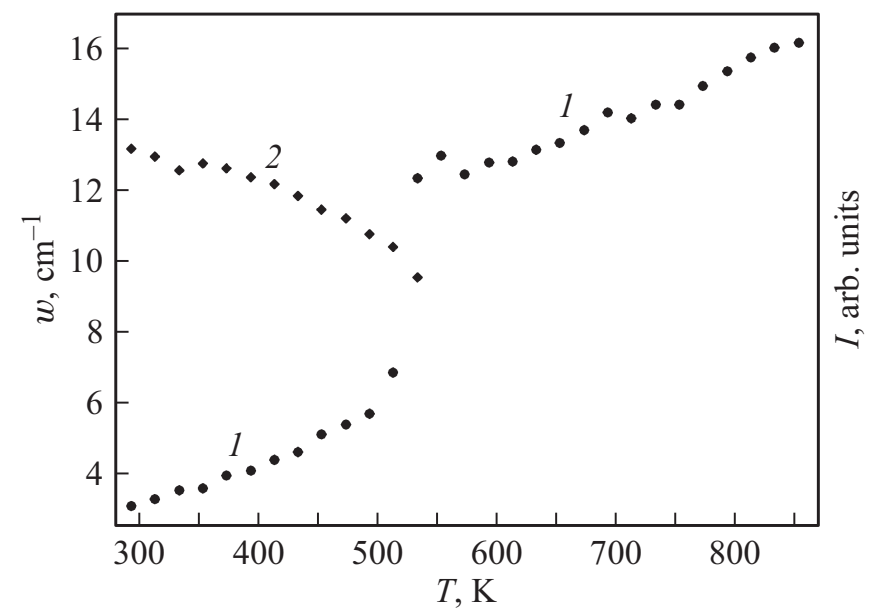

Рис. 10. Температурные зависимости ширины $w(T)$ (1) и интенсивности $I(T)(2)$ спектрального контура $v_{1}(\mathrm{~A})$ аниона $\mathrm{SO}_{4}^{2-}$ в кристаллическом сульфате натрия $\mathrm{Na}_{2} \mathrm{SO}_{4}$.

На рис. 9 представлена температурная зависимость $v(T)$ положения максимума спектральной полосы, соответствующей колебанию $v_{1}(\mathrm{~A})$ аниона $\mathrm{SO}_{4}^{2-}$ в сульфате натрия $\mathrm{Na}_{2} \mathrm{SO}_{4}$. С ростом температуры частота колебания уменьшается. Примерно при $T_{p}=400 \mathrm{~K}$ имеют место определенные особенности температурной зависимости $v(T)$. При дальнейшем увеличении температуры уменьшение частоты происходит более быстро. В точке структурного фазового перехода первого рода $\left(T_{s}=520-525 \mathrm{~K}\right)$ частота резко увеличивается, уменьшаясь при дальнейшем увеличении температуры. Таким образом, в интервале температур от 400 до $520 \mathrm{~K}$ имеет место предпереходная область в сульфате натрия $\mathrm{Na}_{2} \mathrm{SO}_{4}$.

На рис. 10 представлены температурные зависимости $w(T)$ ширины $(1)$ и $I(T)$ интенсивности (2) спектральной полосы, соответствующей колебанию $v_{1}(\mathrm{~A})$ аниона $\mathrm{SO}_{4}^{2-}$ в сульфате натрия $\mathrm{Na}_{2} \mathrm{SO}_{4}$. С ростом температуры ширина возрастает, а интенсивность уменьшается. При температурах, больших чем $T_{p}=400 \mathrm{~K}$, ширина $w(T)$ возрастает, а интенсивность $I(T)$ уменьшается более интенсивно. Ширина полосы резко возрастает в точке структурного фазового перехода первого рода $\left(T_{s}=520-525 \mathrm{~K}\right)$. Таким образом, в интервале температур от 400 до $520 \mathrm{~K}$ имеет место предпереходная область в сульфате натрия $\mathrm{Na}_{2} \mathrm{SO}_{4}$.

На рис. 11 представлена температурная зависимость $v(T)$ положения максимума спектральной полосы, соответствующей колебанию $v_{1}(\mathrm{~A})$ аниона $\mathrm{SO}_{4}^{2-}$ в сульфате калия $\mathrm{K}_{2} \mathrm{SO}_{4}$. С ростом температуры частота колебания уменьшается. Примерно при $T_{p}=650 \mathrm{~K}$ имеют место определенные особенности температурной зависимости $v(T)$. При дальнейшем увеличении температуры частота продолжает уменьшаться. В точке структурного фазового перехода первого рода $\left(T_{s}=854 \mathrm{~K}\right)$ уменьшение частоты приостанавливается. Таким образом, в интервале температур от 650 до $850 \mathrm{~K}$ имеет место предпереходная область в сульфате калия $\mathrm{K}_{2} \mathrm{SO}_{4}$. 


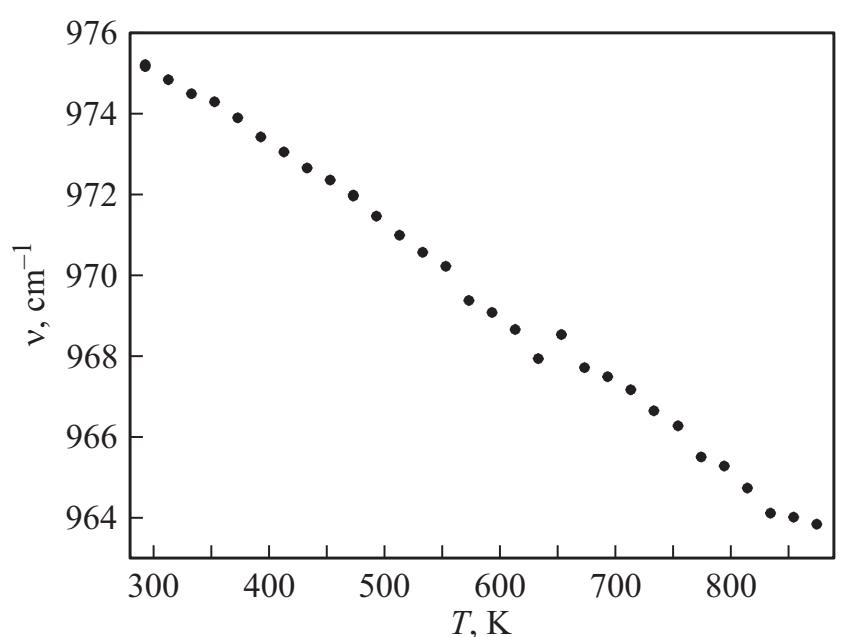

Рис. 11. Температурная зависимость $v(T)$ положения максимума спектрального контура $v_{1}(\mathrm{~A})$ аниона $\mathrm{SO}_{4}^{2-}$ в кристаллическом сульфате калия $\mathrm{K}_{2} \mathrm{SO}_{4}$.

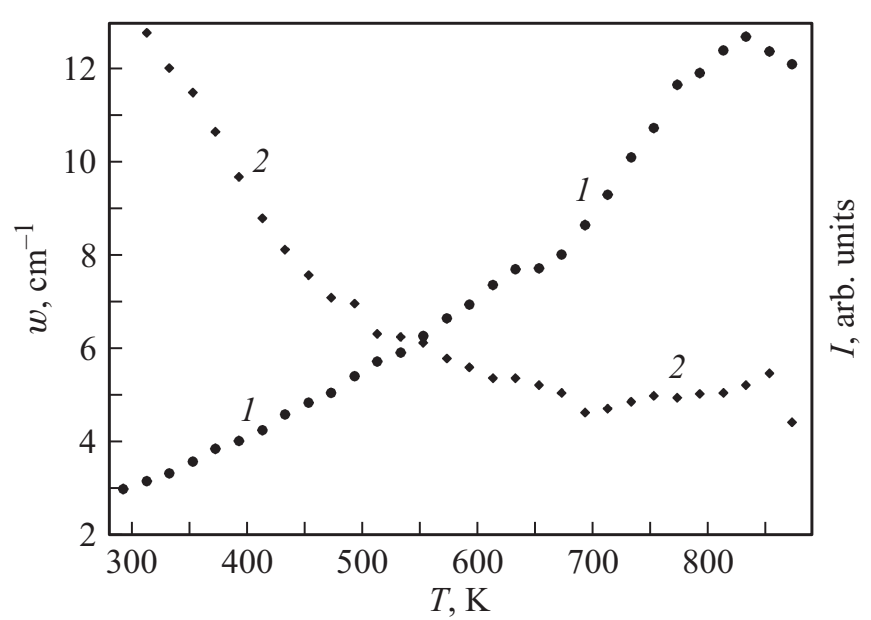

Рис. 12. Температурные зависимости ширины $w(T)(1)$ и интенсивности $I(T)(2)$ спектрального контура $v_{1}(\mathrm{~A})$ аниона $\mathrm{SO}_{4}^{2-}$ в кристаллическом сульфате калия $\mathrm{K}_{2} \mathrm{SO}_{4}$.

На рис. 12 представлены температурные зависимости $w(T)$ ширины $(1)$ и $I(T)$ интенсивности (2) спектральной полосы, соответствующей колебанию $v_{1}(\mathrm{~A})$ аниона $\mathrm{SO}_{4}^{2-}$ в сульфате калия $\mathrm{K}_{2} \mathrm{SO}_{4}$. С ростом температуры ширина возрастает, а интенсивность уменьшается. Примерно при $T_{p}=650 \mathrm{~K}$ имеют место определенные особенности температурных зависимостей $w(T)$ и $I(T)$. Уменьшение интенсивности приостанавливается и в интервале температур 650-850 К интенсивность остается почти постоянной. При структурном фазовом переходе первого рода $\left(T_{s}=854 \mathrm{~K}\right)$ интенсивность уменьшается. Рост ширины при $T_{p}=650 \mathrm{~K}$ приостанавливается, а затем снова ширина начинает увеличиваться. Ближе к структурному фазовому переходу первого рода $\left(T_{s}=854 \mathrm{~K}\right)$ рост ширины замедляется и в точке структурного фазового перехода первого рода $\left(T_{s}=854 \mathrm{~K}\right)$ имеет место уменьшение ширины. Таким образом, в

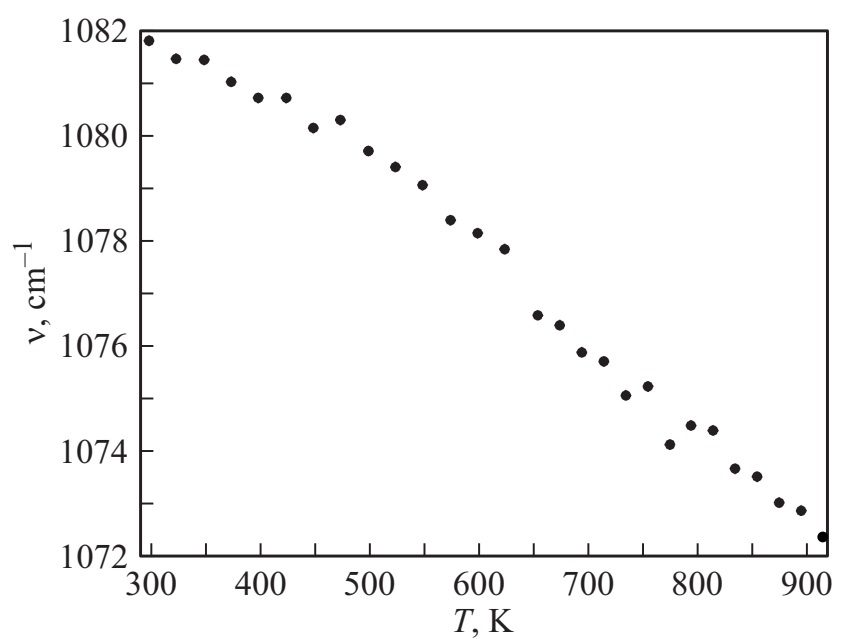

Рис. 13. Температурная зависимость $v(T)$ положения максимума спектрального контура $v_{1}(\mathrm{~A})$ аниона $\mathrm{CO}_{3}^{2-}$ в кристаллическом карбонате лития $\mathrm{Li}_{2} \mathrm{CO}_{3}$.

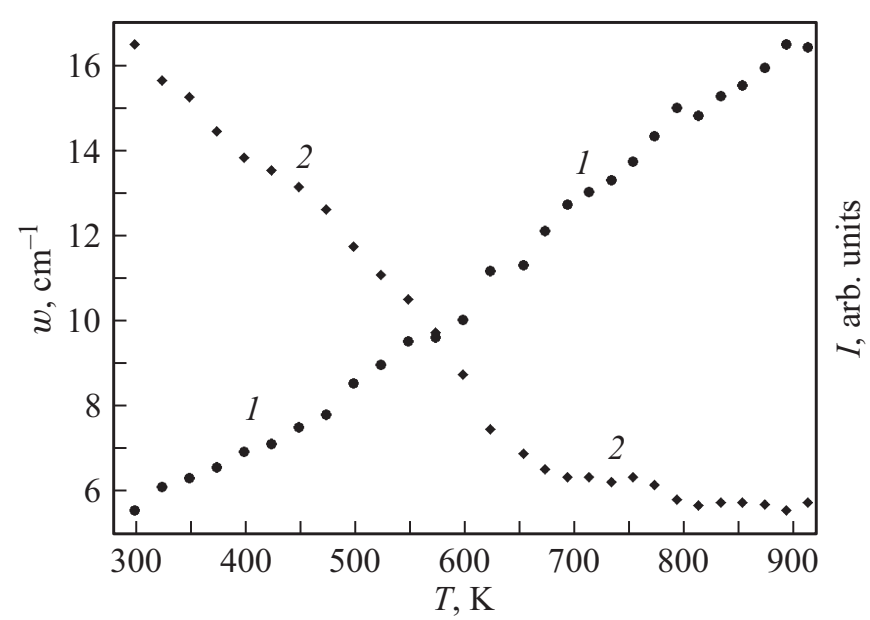

Рис. 14. Температурные зависимости ширины $w(T)(1)$ и интенсивности $I(T)(2)$ спектрального контура $v_{1}(\mathrm{~A})$ аниона $\mathrm{CO}_{3}^{2-}$ в кристаллическом карбонате лития $\mathrm{Li}_{2} \mathrm{CO}_{3}$.

интервале температур от 650 до $850 \mathrm{~K}$ имеет место предпереходная область в сульфате калия $\mathrm{K}_{2} \mathrm{SO}_{4}$.

На рис. 13 представлена температурная зависимость $v(T)$ положения максимума спектральной полосы, соответствующей колебанию $v_{1}(\mathrm{~A})$ аниона $\mathrm{CO}_{3}^{2-}$ в карбонате лития $\mathrm{Li}_{2} \mathrm{CO}_{3}$. С ростом температуры частота колебания уменьшается. Примерно при $T_{p}=550 \mathrm{~K}$ имеют место определенные особенности температурной зависимости $v(T)$. При дальнейшем увеличении температуры уменьшение частоты происходит медленнее. В точке структурного фазового перехода первого рода $\left(T_{s} \approx 650 \mathrm{~K}\right)$ частота резко уменьшается. Таким образом, в интервале температур от 550 до $650 \mathrm{~K}$ имеет место предпереходная область в карбонате лития $\mathrm{Li}_{2} \mathrm{CO}_{3}$.

На рис. 14 представлены температурные зависимости $w(T)$ ширины $(1)$ и $I(T)$ интенсивности (2) спектральной полосы, соответствующей колебанию $v_{1}(\mathrm{~A})$ аниона 


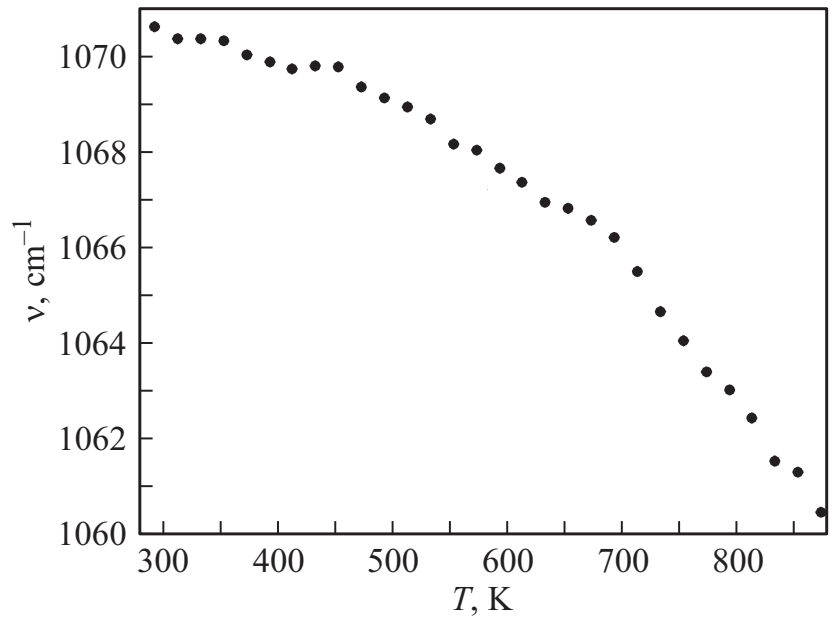

Рис. 15. Температурная зависимость $v(T)$ положения максимума спектрального контура $v_{1}(\mathrm{~A})$ аниона $\mathrm{CO}_{3}^{2-}$ в кристаллическом карбонате натрия $\mathrm{Na}_{2} \mathrm{CO}_{3}$.

$\mathrm{CO}_{3}^{2-}$ в карбонате лития $\mathrm{Li}_{2} \mathrm{CO}_{3}$. С ростом температуры ширина возрастает, а интенсивность уменьшается. Примерно при $T_{p}=550 \mathrm{~K}$ имеют место определенные особенности температурных зависимостей $w(T)$ и $I(T)$. Интенсивность при $T_{p}=550 \mathrm{~K}$ резко уменьшается, а при $650 \mathrm{~K}$ это уменьшение замедляется. Ширина при $T_{p}=550 \mathrm{~K}$ испытывает перегиб, а при $650 \mathrm{~K}$ резко возрастает в точке структурного фазового перехода первого рода. Таким образом, в интервале температур от 550 до $650 \mathrm{~K}$ имеет место предпереходная область в карбонате лития $\mathrm{Li}_{2} \mathrm{CO}_{3}$.

На рис. 15 представлена температурная зависимость $v(T)$ положения максимума спектральной полосы, соответствующей колебанию $v_{1}(\mathrm{~A})$ аниона $\mathrm{CO}_{3}^{2-}$ в карбонате натрия $\mathrm{Na}_{2} \mathrm{CO}_{3}$. С ростом температуры частота колебания уменьшается. Примерно при $T_{p}=520-530 \mathrm{~K}$ имеют место определенные особенности температурной зависимости $v(T)$. При дальнейшем увеличении температуры частота продолжает уменьшаться. В точке структурного фазового перехода первого рода $\left(T_{s}=620-630 \mathrm{~K}\right)$ имеет место определенная особенность температурной зависимости $v(T)$. Таким образом, в интервале температур от 520 до $620 \mathrm{~K}$ имеет место предпереходная область в карбонате натрия $\mathrm{Na}_{2} \mathrm{CO}_{3}$.

На рис. 16 представлены температурные зависимости $w(T)$ ширины $(1)$ и $I(T)$ интенсивности (2) спектральной полосы, соответствующей колебанию $v_{1}(\mathrm{~A})$ аниона $\mathrm{CO}_{3}^{2-}$ в карбонате натрия $\mathrm{Na}_{2} \mathrm{CO}_{3}$. C ростом температуры ширина и интенсивность практически не меняются. При температурах, больших чем $T_{p}=520-530 \mathrm{~K}$, ширина $w(T)$ начинает возрастать, а интенсивность $I(T)$ начинает уменьшаться. Ширина резко возрастает, а интенсивность резко уменьшается в точке структурного фазового перехода первого рода $\left(T_{s}=620-630 \mathrm{~K}\right)$. Таким образом, в интервале температур от 520 до $620 \mathrm{~K}$ имеет место предпереходная область в карбонате натрия $\mathrm{Na}_{2} \mathrm{CO}_{3}$.
На рис. 17 представлена температурная зависимость $v(T)$ положения максимума спектральной полосы, соответствующей колебанию $v_{1}(\mathrm{~A})$ аниона $\mathrm{CO}_{3}^{2-}$ в карбонате калия $\mathrm{K}_{2} \mathrm{CO}_{3}$. С ростом температуры частота колебания уменьшается. Примерно при $T_{p}=600 \mathrm{~K}$ имеют место определенные особенности температурной зависимости $v(T)$. При дальнейшем увеличении температуры частота практически не меняется. В точке структурного фазового перехода первого рода $\left(T_{s}=690-695 \mathrm{~K}\right)$ имеет место скачок частоты вниз. Таким образом, в интервале температур от 600 до $695 \mathrm{~K}$ имеет место предпереходная область в $\mathrm{K}_{2} \mathrm{CO}_{3}$.

На рис. 18 представлены температурные зависимости $w(T)$ ширины $(I)$ и $I(T)$ интенсивности (2) спектральной полосы, соответствующей колебанию $v_{1}(\mathrm{~A})$ аниона $\mathrm{CO}_{3}^{2-}$ в карбонате калия $\mathrm{K}_{2} \mathrm{CO}_{3}$. C ростом температуры ширина возрастает, а интенсивность уменьшает-

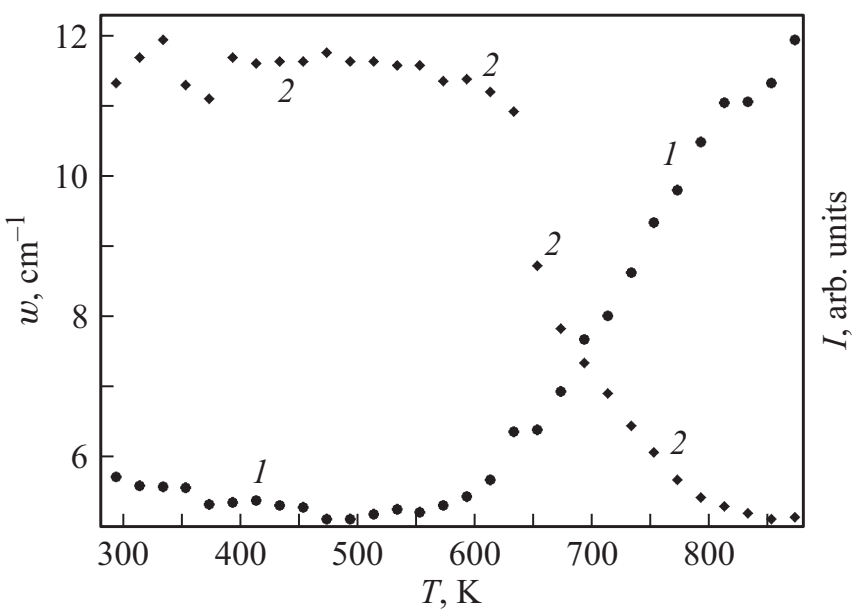

Рис. 16. Температурные зависимости ширины $w(T)(1)$ и интенсивности $I(T)(2)$ спектрального контура $v_{1}(\mathrm{~A})$ аниона $\mathrm{CO}_{3}^{2-}$ в кристаллическом карбонате натрия $\mathrm{Na}_{2} \mathrm{CO}_{3}$.

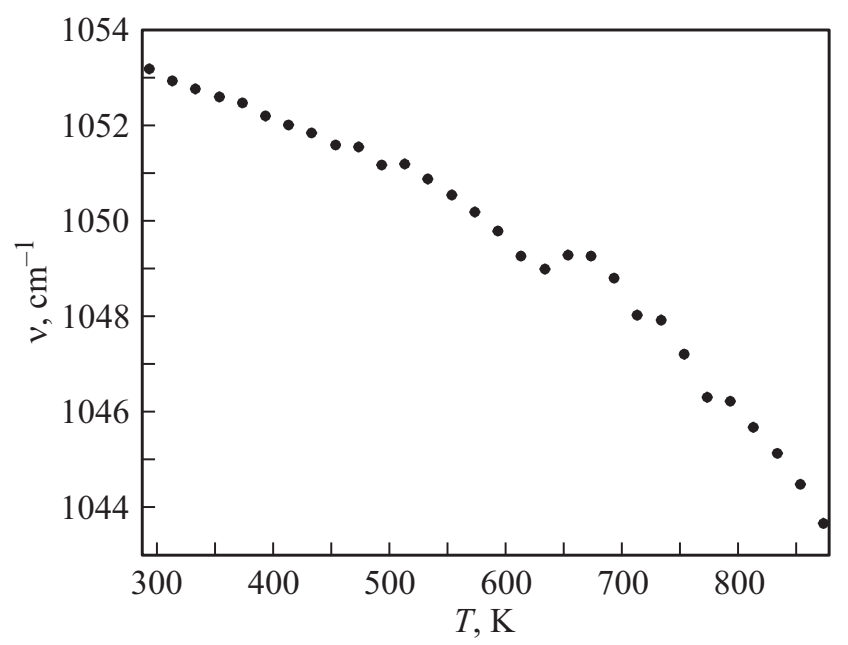

Рис. 17. Температурная зависимость $v(T)$ положения максимума спектрального контура $v_{1}(\mathrm{~A})$ аниона $\mathrm{CO}_{3}^{2-}$ в кристаллическом карбонате калия $\mathrm{K}_{2} \mathrm{CO}_{3}$. 


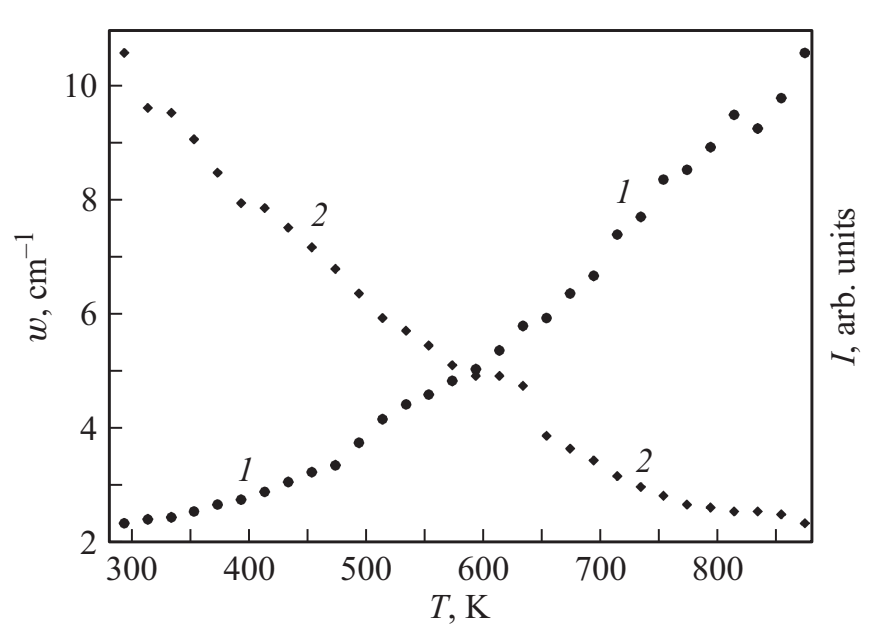

Рис. 18. Температурные зависимости ширины $w(T)(1)$ и интенсивности $I(T)(2)$ спектрального контура $v_{1}(\mathrm{~A})$ аниона $\mathrm{CO}_{3}^{2-}$ в кристаллическом карбонате калия $\mathrm{K}_{2} \mathrm{CO}_{3}$.

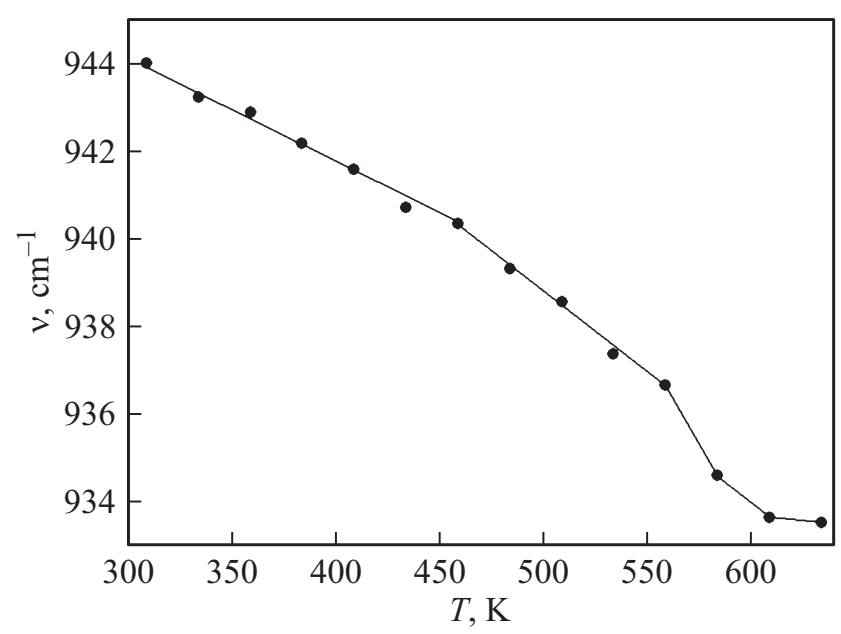

Рис. 19. Температурная зависимость $v(T)$ положения максимума спектрального контура $v_{1}(\mathrm{~A})$ аниона $\mathrm{ClO}_{4}^{-}$в кристаллическом перхлорате натрия $\mathrm{NaClO}_{4}$.

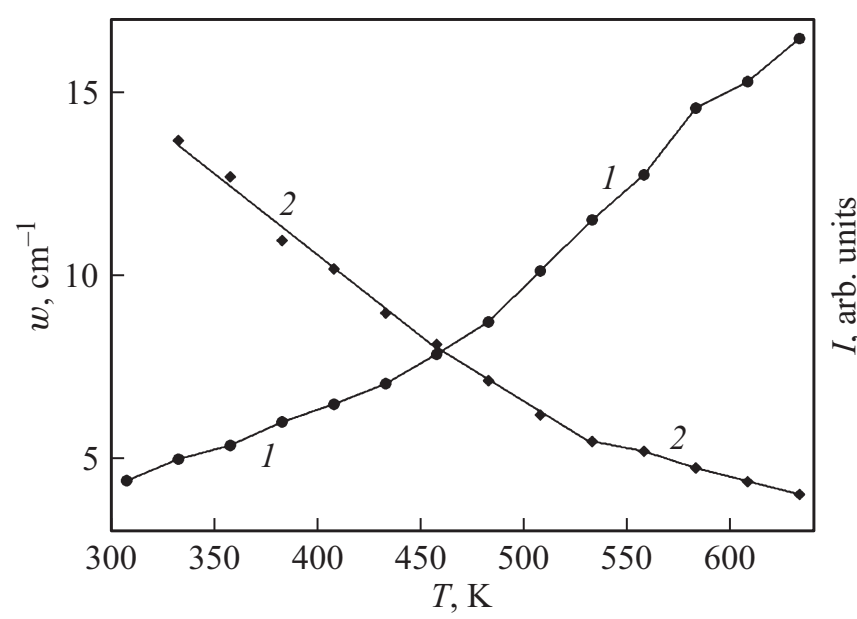

Рис. 20. Температурные зависимости ширины $w(T)(1)$ и интенсивности $I(T)(2)$ спектрального контура $v_{1}(\mathrm{~A})$ аниона $\mathrm{ClO}_{4}^{-}$в кристаллическом перхлорате натрия $\mathrm{NaClO}_{4}$. ся. Примерно при $T_{p}=600 \mathrm{~K}$ имеют место определенные особенности температурных зависимостей $w(T)$ и $I(T)$. Уменьшение интенсивности приостанавливается при $570 \mathrm{~K}$ и в интервале температур 570-640 К интенсивность остается почти постоянной. При структурном фазовом переходе первого рода $\left(T_{s}=690-695 \mathrm{~K}\right)$ интенсивность уменьшается. Рост ширины при $T_{p}-600 \mathrm{~K}$ усиливается и в точке структурного фазового перехода первого рода $\left(T_{s}=690-695 \mathrm{~K}\right)$ имеет место скачок ширины. Таким образом, в интервале температур от 600 до $695 \mathrm{~K}$ имеет место предпереходная область в карбонате калия $\mathrm{K}_{2} \mathrm{CO}_{3}$.

На рис. 19 представлена температурная зависимость $v(T)$ положения максимума спектральной полосы, соответствующей колебанию $v_{1}(\mathrm{~A})$ аниона $\mathrm{ClO}_{4}^{-}$в перхлорате натрия $\mathrm{NaClO}_{4}$. C ростом температуры частота колебания уменьшается. Примерно при $T_{p}=460 \mathrm{~K}$ имеют место определенные особенности температурной зависимости $v(T)$. При дальнейшем увеличении температуры уменьшение частоты происходит более быстро. С точке структурного фазового перехода первого рода $\left(T_{s} \approx 580 \mathrm{~K}\right)$ частота резко уменьшается, уменьшаясь и при дальнейшем увеличении температуры. Таким образом, в интервале температур от 460 до $570 \mathrm{~K}$ имеет место предпереходная область в перхлорате $\mathrm{NaClO}_{4}$.

На рис. 20 представлены температурные зависимости $w(T)$ ширины (1) и $I(T)$ интенсивности (2) спектральной полосы, соответствующей колебанию $v_{1}(\mathrm{~A})$ аниона $\mathrm{ClO}_{4}^{-}$в перхлорате натрия $\mathrm{NaClO}_{4}$. С ростом температуры ширина возрастает, а интенсивность уменьшается. При температурах, больших чем $T_{p}=460 \mathrm{~K}$, ширина $w(T)$ возрастает, а интенсивность $I(T)$ уменьшается более интенсивно. Ширина резко возрастает в точке структурного фазового перехода первого рода $\left(T_{s} \approx 580 \mathrm{~K}\right)$. Таким образом, в интервале температур от 460 до $570 \mathrm{~K}$ имеет место предпереходная область в перхлорате натрия $\mathrm{NaClO}_{4}$.

На рис. 21 представлена температурная зависимость $v(T)$ положения максимума спектральной полосы, со-

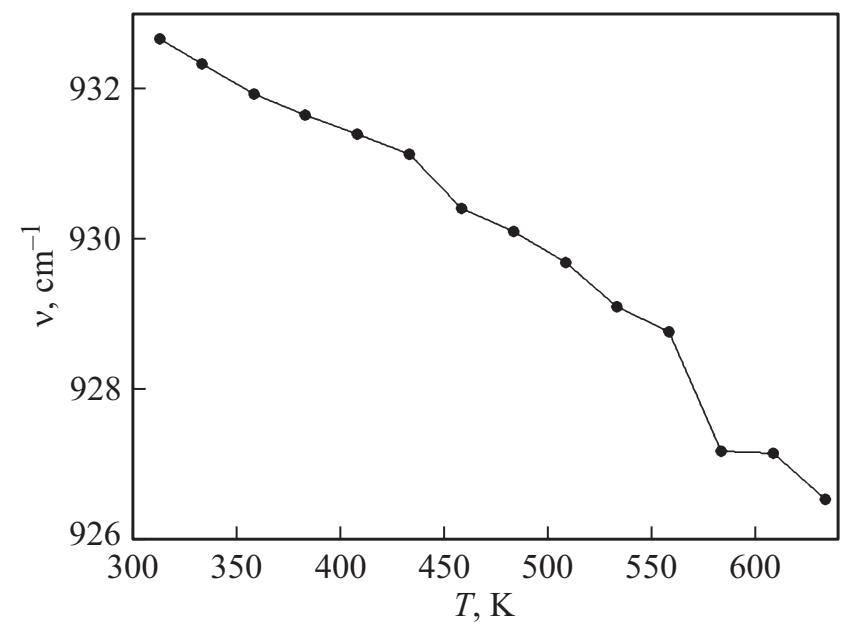

Рис. 21. Температурная зависимость $v(T)$ положения максимума спектрального контура $v_{1}(\mathrm{~A})$ аниона $\mathrm{ClO}_{4}^{-}$в кристаллическом перхлорате калия $\mathrm{KClO}_{4}$. 
ответствующей колебанию $v_{1}(\mathrm{~A})$ аниона $\mathrm{ClO}_{4}^{-}$в перхлорате калия $\mathrm{KClO}_{4}$. С ростом температуры частота колебания уменьшается. Примерно при $T_{p}=450 \mathrm{~K}$ имеют место определенные особенности температурной зависимости $v(T)$ - наблюдается небольшой скачок частоты вниз. При дальнейшем увеличении температуры частота продолжает уменьшаться более быстро. В точке структурного фазового перехода первого рода $\left(T_{s} \approx 571-573 \mathrm{~K}\right)$ частота резко уменьшается, уменьшаясь и при дальнейшем увеличении температуры. Таким образом, в интервале температур от 450 до $570 \mathrm{~K}$ имеет место предпереходная область в перхлорате калия $\mathrm{KClO}_{4}$.

На рис. 22 представлены температурные зависимости $w(T)$ ширины $(1)$ и $I(T)$ интенсивности (2) спектральной полосы, соответствующей колебанию $v_{1}(\mathrm{~A})$ аниона $\mathrm{ClO}_{4}^{-}$в перхлорате калия $\mathrm{KClO}_{4}$. С ростом температуры ширина возрастает, а интенсивность уменьшается. В интервале температур 400-500 К имеют место определенные особенности температурных зависимостей $w(T)$ и $I(T)$. Излом на температурной зависимости интенсивности $I(T)$ наблюдается при температуре $T_{p}=400 \mathrm{~K}$, а на температурной зависимости ширины $w(T)-$ при $500 \mathrm{~K}$. При структурном фазовом переходе первого рода $\left(T_{s} \approx 571-573 \mathrm{~K}\right)$ интенсивность уменьшается, а ширина резко возрастает. При дальнейшем увеличении температуры ширина продолжает возрастать, а интенсивность - уменьшаться. Таким образом, в интервале температур от 450 до $570 \mathrm{~K}$ имеет место предпереходная область в перхлорате калия $\mathrm{KClO}_{4}$.

На рис. 23 представлена температурная зависимость $v(T)$ положения максимума спектральной полосы, соответствующей колебанию $v_{1}(\mathrm{~A})$ аниона $\mathrm{NO}_{3}^{-}$в нитрате кальция $\mathrm{Ca}\left(\mathrm{NO}_{3}\right)_{2}$. C ростом температуры частота колебания уменьшается. Примерно при $T_{p}=750 \mathrm{~K}$ имеют место определенные особенности температурной зависимости $v(T)$. При дальнейшем увеличении температуры уменьшение частоты происходит более быстро. В точке плавления $\left(T_{m}=834 \mathrm{~K}\right)$ частота резко уменьшается.

На рис. 24 представлены температурные зависимости $w(T)$ ширины $(I)$ и $I(T)$ интенсивности (2) спектральной полосы, соответствующей колебанию $v_{1}(\mathrm{~A})$ аниона $\mathrm{NO}_{3}^{-}$в нитрате кальция $\mathrm{Ca}\left(\mathrm{NO}_{3}\right)_{2}$. С ростом температуры ширина возрастает, а интенсивность уменьшается. При температурах, больших чем $T_{p}=750 \mathrm{~K}$, ширина $w(T)$ возрастает, а интенсивность $I(T)$ уменьшается более интенсивно.

Для нитрата кальция $\mathrm{Ca}\left(\mathrm{NO}_{3}\right)_{2}$ в интервале температур от $T_{p}=750 \mathrm{~K}$ до $T_{m}=834 \mathrm{~K}$ мы наблюдаем отклонение температурной зависимости частоты (рис. 23), ширины и интенсивности (рис. 24) от линейных зависимостей, характерных для более низких температур. Эти отклонения появляются при $T_{p}=750 \mathrm{~K}$ и возрастают по мере увеличения температуры и приближения к температуре плавления $T_{m}=834 \mathrm{~K}$. Поэтому мы рассматриваем интервал температур от $T_{p}=750 \mathrm{~K}$ до $T_{m}=834 \mathrm{~K}$ как область предплавления.

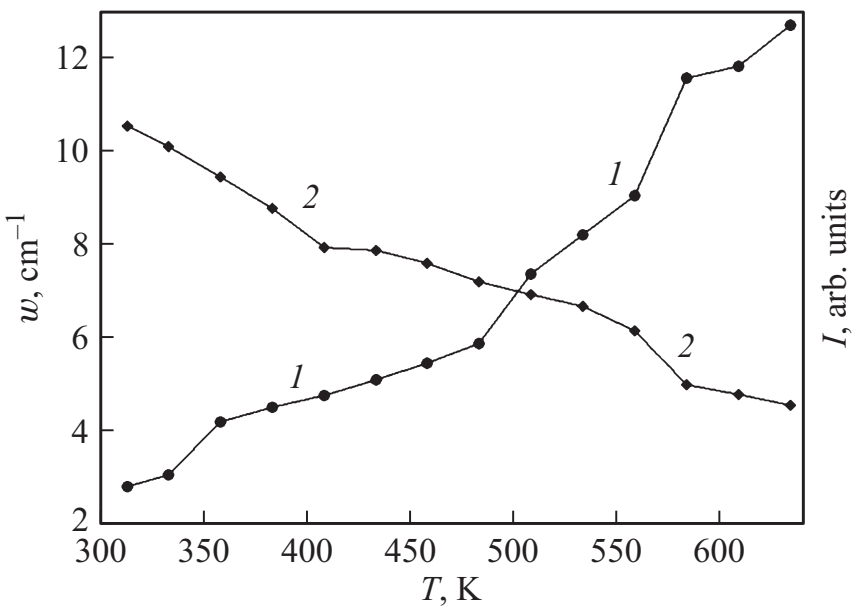

Рис. 22. Температурные зависимости ширины $w(T)(1)$ и интенсивности $I(T)(2)$ спектрального контура $v_{1}(\mathrm{~A})$ аниона $\mathrm{ClO}_{4}^{-}$в кристаллическом перхлорате калия $\mathrm{KClO}_{4}$.

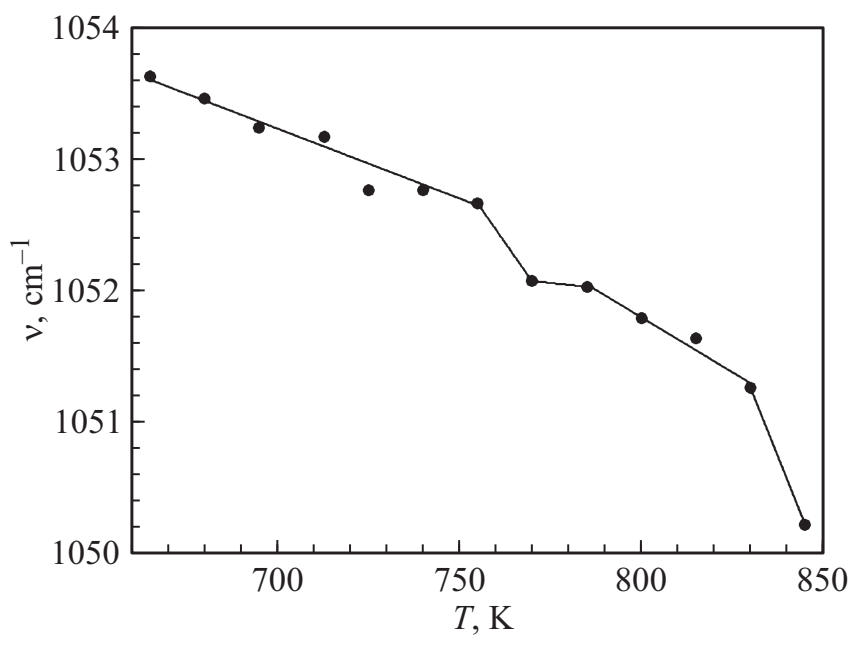

Рис. 23. Температурная зависимость $v(T)$ положения максимума спектрального контура $v_{1}(\mathrm{~A})$ аниона $\mathrm{NO}_{3}^{-}$в нитрате кальция $\mathrm{Ca}\left(\mathrm{NO}_{3}\right)_{2}$.

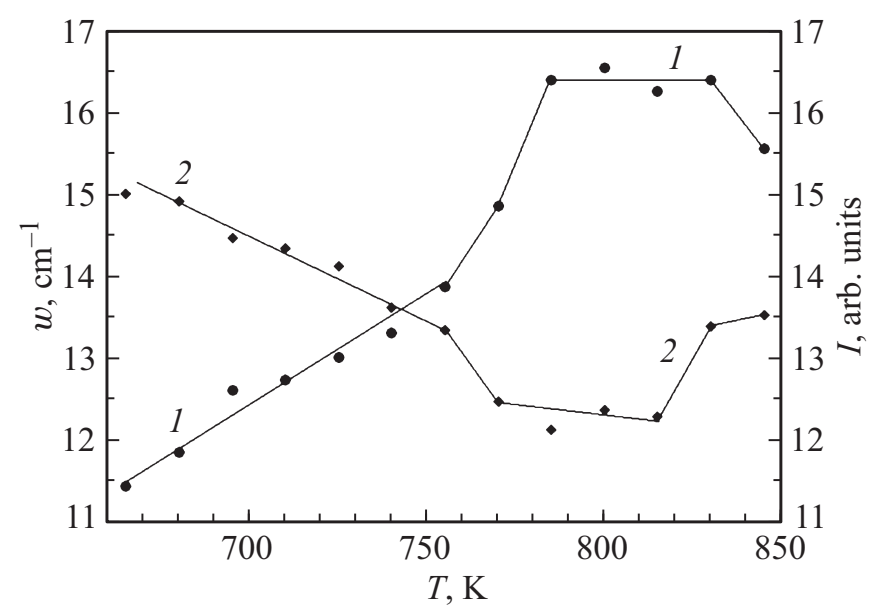

Рис. 24. Температурные зависимости ширины $w(T)$ (1) и интенсивности $I(T)(2)$ спектрального контура $v_{1}(\mathrm{~A})$ аниона $\mathrm{NO}_{3}^{-}$в нитрате кальция $\mathrm{Ca}\left(\mathrm{NO}_{3}\right)_{2}$. 


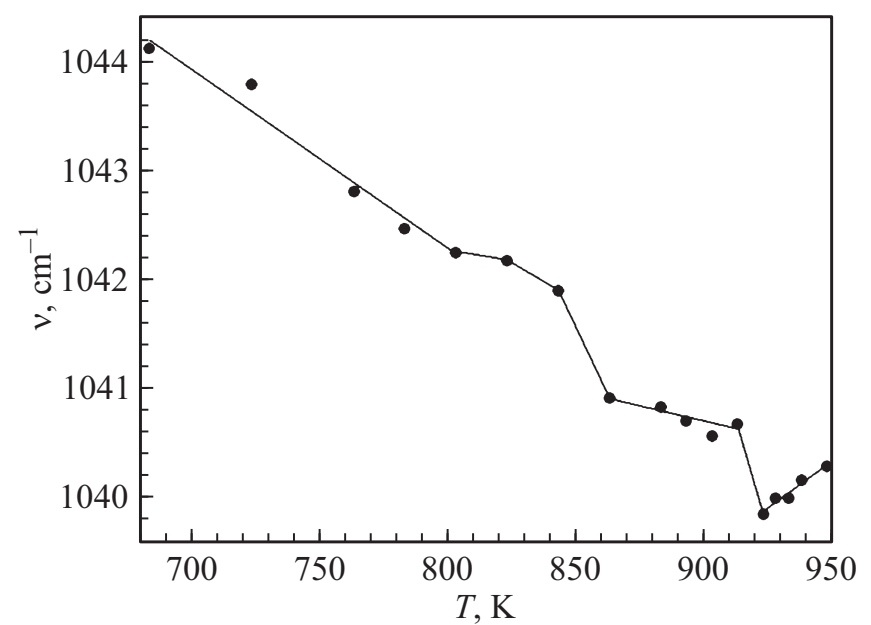

Рис. 25. Температурная зависимость $v(T)$ положения максимума спектрального контура $v_{1}(\mathrm{~A})$ аниона $\mathrm{NO}_{3}^{-}$в нитрате стронция $\mathrm{Sr}\left(\mathrm{NO}_{3}\right)_{2}$.

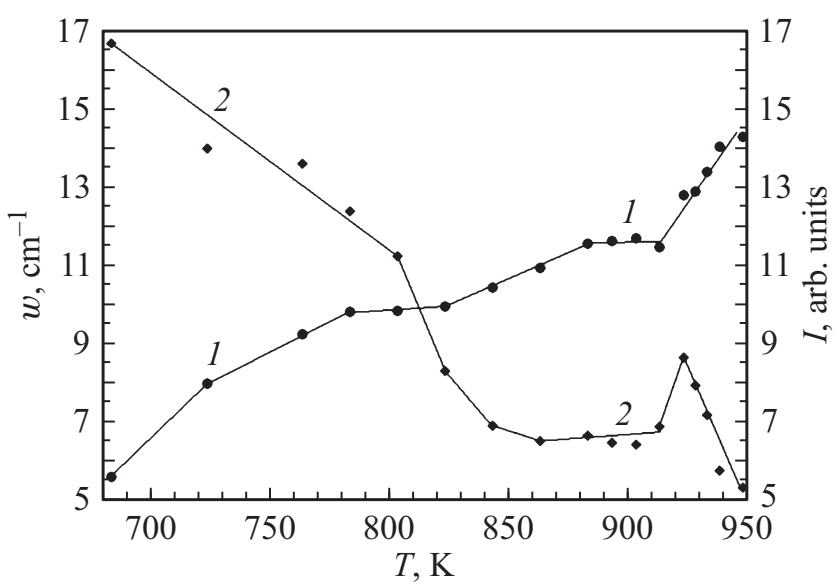

Рис. 26. Температурные зависимости ширины $w(T)(1)$ и интенсивности $I(T)(2)$ спектрального контура $v_{1}(\mathrm{~A})$ аниона $\mathrm{NO}_{3}^{-}$в нитрате стронция $\mathrm{Sr}\left(\mathrm{NO}_{3}\right)_{2}$.

На рис. 25 представлена температурная зависимость $v(T)$ положения максимума спектральной полосы, соответствующей колебанию $v_{1}(\mathrm{~A})$ аниона $\mathrm{NO}_{3}^{-}$в нитрате стронция $\mathrm{Sr}\left(\mathrm{NO}_{3}\right)_{2}$. C ростом температуры частота колебания уменьшается. Примерно при $T_{p}=800 \mathrm{~K}$ имеют место определенные особенности температурной зависимости $v(T)$. При дальнейшем увеличении температуры уменьшение частоты происходит более быстро. В точке плавления $\left(T_{m}=918 \mathrm{~K}\right)$ частота резко уменьшается.

На рис. 26 представлены температурные зависимости $w(T)$ ширины $(1)$ и $I(T)$ интенсивности (2) спектральной полосы, соответствующей колебанию $v_{1}(\mathrm{~A})$ аниона $\mathrm{NO}_{3}^{-}$в нитрате стронция $\mathrm{Sr}\left(\mathrm{NO}_{3}\right)_{2}$. С ростом температуры ширина возрастает, а интенсивность уменьшается. При температурах, больших чем $T_{p}=800 \mathrm{~K}$, ширина $w(T)$ возрастает менее интенсивно, а интенсивность $I(T)$ уменьшается более интенсивно. В точке плавления $\left(T_{m}=918 \mathrm{~K}\right)$ ширина и интенсивность резко возрастают.
Для нитрата стронция $\mathrm{Sr}\left(\mathrm{NO}_{3}\right)_{2}$ в интервале температур от $T_{p}=800 \mathrm{~K}$ до $T_{m}=918 \mathrm{~K}$ мы наблюдаем отклонение температурной зависимости частоты (рис. 25), ширины и интенсивности (рис. 26) от линейных зависимостей, характерных для более низких температур. Эти отклонения появляются при $T_{p}=800 \mathrm{~K}$ и возрастают по мере увеличения температуры и приближения к температуре плавления $T_{m}=918 \mathrm{~K}$. Поэтому мы рассматриваем интервал температур от $T_{p}=800 \mathrm{~K}$ до $T_{m}=918 \mathrm{~K}$ как область предплавления.

На рис. 27 представлена температурная зависимость $v(T)$ положения максимума спектральной полосы, соответствующей колебанию $v_{1}(\mathrm{~A})$ аниона $\mathrm{NO}_{3}^{-}$в нитрате бария $\mathrm{Ba}\left(\mathrm{NO}_{3}\right)_{2}$. C ростом температуры частота колебания уменьшается. Примерно при $T_{p}=780-790 \mathrm{~K}$ имеют место определенные особенности температурной зависимости $v(T)$. При дальнейшем увеличении температуры уменьшение частоты происходит более быстро. В точке плавления $\left(T_{m}=868 \mathrm{~K}\right)$ частота резко уменьшается.

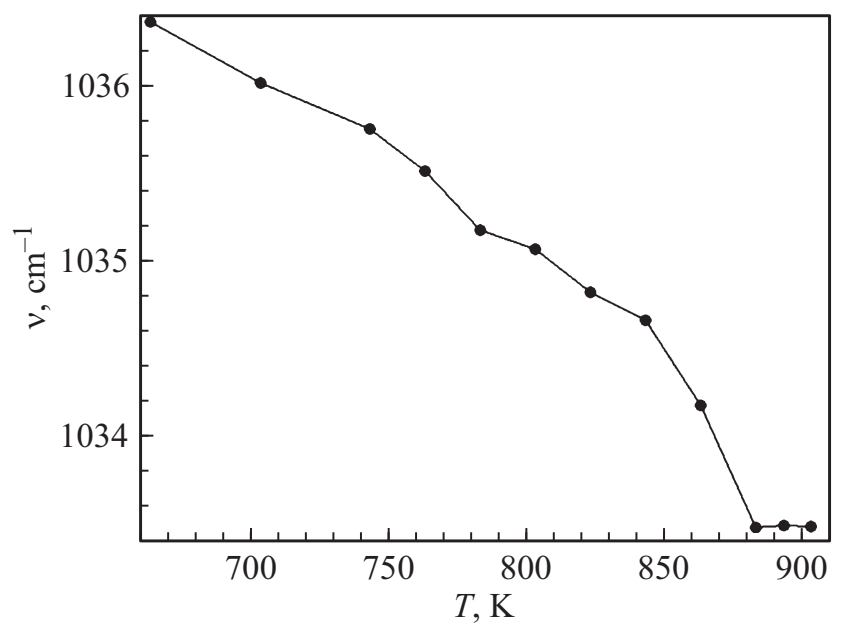

Рис. 27. Температурная зависимость $v(T)$ положения максимума спектрального контура $v_{1}(\mathrm{~A})$ аниона $\mathrm{NO}_{3}^{-}$в нитрате бария $\mathrm{Ba}\left(\mathrm{NO}_{3}\right)_{2}$.

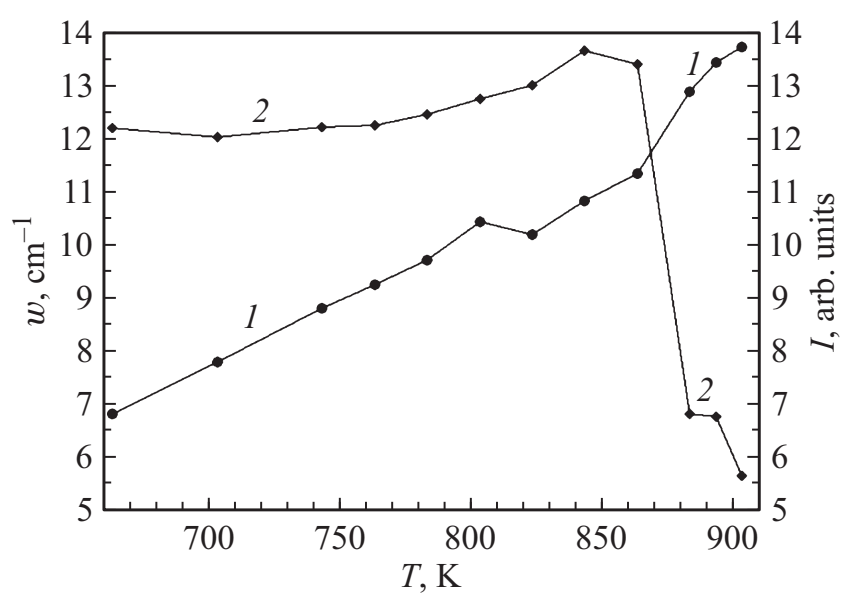

Рис. 28. Температурные зависимости ширины $w(T)$ (1) и интенсивности $I(T)(2)$ спектрального контура $v_{1}(\mathrm{~A})$ аниона $\mathrm{NO}_{3}^{-}$в нитрате бария $\mathrm{Ba}\left(\mathrm{NO}_{3}\right)_{2}$. 
На рис. 28 представлены температурные зависимости $w(T)$ ширины (1) и $I(T)$ интенсивности (2) спектральной полосы, соответствующей колебанию $v_{1}(\mathrm{~A})$ аниона $\mathrm{NO}_{3}^{-}$в нитрате бария $\mathrm{Ba}\left(\mathrm{NO}_{3}\right)_{2}$. С ростом температуры ширина возрастает, а интенсивность практически не меняется. При температурах, больших чем $T_{p}=790-800 \mathrm{~K}$, ширина $w(T)$ испытывает скачок, а интенсивность $I(T)$ начинает возрастать. В точке плавления $\left(T_{m}=868 \mathrm{~K}\right)$ ширина возрастает, а интенсивность резко уменьшается.

Для нитрата бария $\mathrm{Ba}\left(\mathrm{NO}_{3}\right)_{2}$ в интервале температур от $T_{p}=780 \mathrm{~K}$ до $T_{m}=868 \mathrm{~K}$ мы наблюдаем отклонение температурной зависимости частоты (рис. 27), ширины и интенсивности (рис. 28) от линейных зависимостей, характерных для более низких температур. Эти отклонения появляются при $T_{p}=780-800 \mathrm{~K}$ и возрастают по мере увеличения температуры и приближения к температуре плавления $T_{m}=868 \mathrm{~K}$. Поэтому мы рассматриваем интервал температур от $T_{p}=780 \mathrm{~K}$ до $T_{m}=868 \mathrm{~K}$ как область предплавления.

Измеряемые нами спектральные величины (частота, ширина и интенсивность спектральной полосы) это микроскопические параметры. Частота $v$ (положение максимума спектральной полосы) определяется энергией основного внутримолекулярного колебательного перехода аниона. Ширина $w$ спектральной полосы обратно пропорциональна времени $\tau$ релаксации колебательно возбужденного состояния аниона: $w=(\pi \cdot c \cdot \tau)^{-1}, \quad c=3 \cdot 10^{10} \mathrm{~cm} / \mathrm{s}$. Время релаксации имеет порядок $\tau \sim 10^{-12} \mathrm{~s}$. Эти параметры $v, w$ характеризуют отдельные анионы. Они также зависят от того, в каком окружении находится отдельный анион. Если окружение аниона меняется, то меняются и частота, ширина и интенсивность спектральной полосы. Эти микроскопические величины более чувствительны, чем тепловые макроскопические параметры. Микроскопичность спектральных параметров заключается в том, что каждый отдельный анион имеет частоту внутреннего колебания и время колебательной релаксации. В эксперименте мы наблюдаем их усредненные значения. В отличие от этого тепловые величины являются макроскопическими, так как отдельный анион не обладает тепловыми величинами. Только у совокупности большого числа молекул или ионов появляются тепловые параметры и в этом смысле они являются макроскопическими.

Из рис. 7-28 видно, что при температурах, больших чем $T_{p}=T_{s}-100 \mathrm{~K}$ или $T_{p}=T_{m}-100 \mathrm{~K}$, наблюдаются изменения в температурных зависимостях частоты, ширины и интенсивности спектральной полосы. Эти изменения тем сильнее, чем ближе к температуре перехода $T_{s}$ или $T_{m}$ (рис. 2-7). Такие спектральные изменения связаны со структурными изменениями в окружении аниона на микроскопическом уровне. И эти структурные изменения тем сильнее, чем ближе к температуре перехода $T_{s}$ или $T_{m}$. Таким образом, мы приходим к выводу о том, что при температурах, больших чем $T_{p}$, наблюдаются предпереходные явления и проявляются они тем сильнее, чем ближе к температуре фазового перехода первого рода. Следовательно, в интервалах температур от $T_{p}$ до $T_{s}$ имеют место области предперехода в сульфатах $\mathrm{Li}_{2} \mathrm{SO}_{4}, \mathrm{Na}_{2} \mathrm{SO}_{4}, \mathrm{~K}_{2} \mathrm{SO}_{4}$, карбонатах $\mathrm{Li}_{2} \mathrm{CO}_{3}, \mathrm{Na}_{2} \mathrm{CO}_{3}, \mathrm{~K}_{2} \mathrm{CO}_{3}$ и перхлоратах $\mathrm{NaClO}_{4}, \mathrm{KClO}_{4}$, а в интервалах температур от $T_{p}$ до $T_{m}$ имеют место области предплавления в нитратах $\mathrm{Ca}\left(\mathrm{NO}_{3}\right)_{2}, \mathrm{Sr}\left(\mathrm{NO}_{3}\right)_{2}$, $\mathrm{Ba}\left(\mathrm{NO}_{3}\right)_{2}$.

\section{5. Заключение}

Методами спектроскопии комбинационного рассеяния (КР) исследованы процессы молекулярной релаксации в сульфатах $\mathrm{Li}_{2} \mathrm{SO}_{4}, \mathrm{Na}_{2} \mathrm{SO}_{4}, \mathrm{~K}_{2} \mathrm{SO}_{4}$, карбонатах $\mathrm{Li}_{2} \mathrm{CO}_{3}, \mathrm{Na}_{2} \mathrm{CO}_{3}, \mathrm{~K}_{2} \mathrm{CO}_{3}$, перхлоратах $\mathrm{NaClO}_{4}, \mathrm{KClO}_{4}$ и нитратах $\mathrm{Ca}\left(\mathrm{NO}_{3}\right)_{2}, \mathrm{Sr}\left(\mathrm{NO}_{3}\right)_{2}, \mathrm{Ba}\left(\mathrm{NO}_{3}\right)_{2}$. Установлено, что в исследованных системах фазовые переходы первого рода носят растянутый характер: в сульфатах, карбонатах и перхлоратах - это структурные фазовые переходы, а в нитратах - это фазовый переход „кристалл-расплав“ОंОбнаружено существование предпереходной области во всех исследованных кристаллах.

\section{Конфликт интересов}

Авторы заявляют, что у них нет конфликта интересов.

\section{Список литературы}

[1] С.В. Карпов, Т. Краевский, К.В. Тимофеев. ФТТ 37, 2257 (1995).

[2] М.Б. Смирнов, J. Hinka. ФТТ 42, 2219 (2000).

[3] В.И. Зиненко, Н.Г. Замкова. ФТТ 43, 2193 (2001).

[4] Jianjun Liu, Chun-gang Duan, W.N. Mei, R.W. Smith, J.R. Hardy. J. Solid State Chem. 163, 294 (2002).

[5] А.А. Прохоров, Г.Н. Нейло, А.Д. Прохоров, А.С. Карначев. ФTT 48, 321 (2006).

[6] Ю.Н. Журавлев, Д.В. Корабельников. ФТТ 51, 65 (2009).

[7] M. Pravica, Y. Wang, D. Sneed, Sh. Reiser, M. White. Chem. Phys. Lett. 660, 37 (2016).

[8] Д.В. Корабельников, Ю.Н. Журавлев. ФТТ 58, 1129 (2016).

[9] Д.В. Корабельников, Ю.Н. Журавлев. ФТТ 59, 248 (2017).

[10] Е.С. Иванова, Е.А. Петржик, Р.В. Гайнутдинов, А.К. Лашкова, Т.Р. Волк. ФТТ 59, 550 (2017).

[11] А.Р. Алиев, И.Р. Ахмедов, М.Г. Какагасанов, З.А. Алиев, М.М. Гафуров, К.Ш. Рабаданов, А.М. Амиров. ФТТ 59, 736 (2017).

[12] В.С. Бондарев, Е.А. Михалёва, И.Н. Флёров, М.В. Горев. ФTT 59, 1097 (2017).

[13] А.Р. Алиев, И.Р. Ахмедов, М.Г. Какагасанов, З.А. Алиев, М.М. Гафуров, К.Ш. Рабаданов, А.М. Амиров. ФТТ 60, 341 (2018).

[14] Nguyen Hoai Thu'o'ng, А.С. Сидоркин, С.Д. Миловидова. ФTT 60, 553 (2018).

[15] Е.А. Михалева, И.Н. Флёров, А.В. Карташев, М.В. Горев, М.С. Молокеев, Л.Н. Коротков, Е. Rysiakiewicz-Pasek. ФТТ 60, 1328 (2018).

[16] Д.В. Корабельников, Ю.Н. Журавлев. ФТТ 60, 2014 (2018). 
[17] А. Уббелоде. Плавление и кристаллическая структура. Мир, М. (1969). С. 279.

[18] Г.Д. Копосов, Д.Ю. Бардюг. Письма в ЖТФ 33, 14, 80 (2007).

[19] Е.И. Демихов, В.К. Долганов, В.М. Филев. Письма в ЖЭТФ 37, 305 (1983).

[20] М.А. Анисимов, Е.Е. Городецкий, В.Э. Поднек. Письма в ЖЭТФ 37, 352 (1983).

[21] Е.И. Демихов, В.К. Долганов. Письма в ЖЭТФ 38, 368 (1983).

[22] В.А. Кизель, С.И. Панин. Письма в ЖЭТФ 44, 74 (1986).

[23] В.Г. Пушин, В.В. Кондратьев, В.Н. Хачин. Предпереходные явления и мартенситные превращения. УрО РАН, Екатеринбург (1998). 367 с.

[24] А.А. Клопотов, Т.Л. Чекалкин, В.Э. Гюнтер. ЖТФ 71, 6, 130 (2001).

[25] Е.И. Кузнецова. Модулированные структуры, предпереходные явления и свойства металлических сплавов ( $\mathrm{Ni}-\mathrm{Al})$ и оксидов $\mathrm{Y}(\mathrm{Eu})-\mathrm{Ba}-\mathrm{Cu}-\mathrm{O}$. Дис. канд. физ.-мат. наук. Институт физики металлов УрО РАН, Екатеринбург (2003). $115 \mathrm{c}$.

[26] В.Н. Гришков, А.И. Лотков, С.Ф. Дубинин, С.Г. Теплоухов, В.Д. Пархоменко. ФТТ 46, 1348 (2004).

[27] С.В. Мельникова, Л.И. Исаенко, В.М. Пашков, И.В. Певнев. ФТТ 47, 319 (2005).

[28] С.В. Мельникова, В.Д. Фокина, Н.М. Лапташ. ФТТ 48, 110 (2006).

[29] С.В. Мельникова, Л.И. Исаенко, В.М. Пашков, И.В. Певнев. ФТТ 48, 2032 (2006).

[30] С.В. Мельникова, Н.М. Лапташ, К.С. Александров. ФТТ 52, 2023 (2010).

[31] Е.Е. Слядников. ФТТ 46, 1065 (2004).

[32] Е.Е. Слядников. Письма в ЖТФ 31, 5, 30 (2005).

[33] Е.Е. Слядников. ФТТ 47, 469 (2005).

[34] Е.Е. Слядников. Предпереходные состояния и коллективные возбуждения в структурнонеустойчивых кристаллах. Дис. докт. физ.-мат. наук. Институт физики прочности и материаловедения СО РАН, Томск (2005). 259 с.

[35] А.П. Беляев, В.П. Рубец, В.В. Антипов, Н.С. Бордей. ЖТФ 84, 7, 156 (2014).

[36] В.И. Максимов, С.Ф. Дубинин, Т.П. Суркова. ФТТ 56, 2311 (2014).

[37] В.И. Максимов, Т.П. Суркова, В.Д. Пархоменко, Е.Н. Юшкова. ФТТ 58, 633 (2016).

[38] А.П. Беляев, В.П. Рубец, В.В. Антипов. ЖТФ 87, 4, 624 (2017).

[39] А.Р. Алиев, М.М. Гафуров, И.Р. Ахмедов, М.Г. Какагасанов, 3.А. Алиев. ФТТ 60, 1191 (2018).

[40] В.И. Максимов, Е.Н. Максимова, Т.П. Суркова, А.П. Вохмянин. ФТТ 61, 42 (2019).

[41] А.Н. Втюрин, А. Белю, А.С. Крылов, М.Л. Афанасьев, А.П. Шебанин. ФТТ 43, 2209 (2001).

[42] Рассеяние света вблизи точек фазовых переходов / Под ред. Г.З. Камминза, А.П. Леванюка. Наука, Москва (1990). $414 \mathrm{c}$.

[43] С.В. Карпов, А.А. Шултин. ФТТ 17, 2868 (1975).

[44] Я.Я. Аболиньш, С.В. Карпов, А.А. Шултин. ФТТ 20, 3660 (1978).

[45] M.M. Gafurov, A.R. Aliev, I.R. Akhmedov. Spectrochim. Acta 58A, 2683 (2002).
[46] Химическая энциклопедия. Сов. энциклопедия, М. (1988). T. 1. C. 243 ; (1990). T. 2. C. 288,289 , 297, 607, 608; (1992). T. 3. C. 182 , 184, 185 , 497; (1995). T. 4. C. $183,184$.

[47] C.W. Bale, A.D. Pelton. CALPHAD 6, 255 (1982).

[48] Y. Dessureault, J. Sangster, A.D. Pelton. J. Electrochem. Soc. 137, 2941 (1990).

[49] D. Lindberg, R. Backman, P. Chartrand. J. Chem. Thermodynam. 39, 942 (2007).

[50] A.R. Aliev, M.M. Gafurov, I.R. Akhmedov. Mol. Phys. 100, 3385 (2002).

[51] A.R. Aliev, M.M. Gafurov, I.R. Akhmedov. Chem. Phys. Lett. 359, 262 (2002).

[52] A.R. Aliev, M.M. Gafurov, I.R. Akhmedov. Chem. Phys. Lett. 353, 270 (2002).

[53] A.R. Aliev, A.Z. Gadzhiev. J. Mol. Liquids 107, 59 (2003).

[54] A.R. Aliev, M.M. Gafurov, I.R. Akhmedov. Chem. Phys. Lett. 378, 155 (2003).

[55] А.Р. Алиев, И.Р. Ахмедов, М.Г. Какагасанов, 3.А. Алиев, М.М. Гафуров, К.Ш. Рабаданов, А.М. Амиров. Оптика и спектроскопия 123, 575 (2017).

Редактор Ю.Э. Китаев

Публикация трудов Конференции завершена. 